\title{
Prawo sprawdzenia prawomocnych orzeczeń sądów polskich (nieniemieckich) w Generalnym Gubernatorstwie w okresie II wojny światowej. Orzecznictwo Wyższego Sądu Niemieckiego w Radomiu ${ }^{1}$
}

\begin{abstract}
WSTĘP
Generalne Gubernatorstwo (dalej jako: GG) zostało utworzone na mocy dekretu Führera i Kanclerza Rzeszy Niemieckiej o administracji okupowanych polskich obszarów z 12 października 1939 r., który wszedł w życie dwa tygodnie później². W GG stworzony został dualistyczny model sądownictwa powszechnego, jeden pion przeznaczony był dla ludności niemieckiej, drugi dla pozostałych narodowości zamieszkujących $\mathrm{GG}^{3}$. Podobnie jak w innych dziedzinach życia w GG, także sądy polskie (nieniemieckie) ${ }^{4}$, w których pracowali w większości sędziowie naro-

${ }^{1}$ Publikacja została przygotowana w ramach projektu badawczego „Charakter prawny i rola tez prawnych uchwalanych przez polskie (nieniemieckie) sądy apelacyjne w Generalnym Gubernatorstwie w okresie II wojny światowej”, finansowanego ze środków Narodowego Centrum Nauki na podstawie umowy nr UMO-2017/27/N/HS5/00812.

${ }^{2}$ A. Weh, Prawo Generalnego Gubernatorstwa w układzie rzeczowym z objaśnieniami i szczegółowym skorowidzem, Kraków 1941, A100.

3 Więcej na temat właściwości osobowej sądownictwa niemieckiego: A. Wrzyszcz, Okupacyjne sadownictwo niemieckie w Generalnym Gubernatorstwie 1939-1945. Organizacja i funkcjonowanie, Lublin 2008, s. 220-222.

${ }^{4}$ Określenie „sądownictwo polskie” pochodzi z języka prawnego Generalnego Gubernatorstwa. Po raz pierwszy pojęcie „sądownictwo nieniemieckie” pojawiło się w rozporządzeniu w sprawie odbudowy wymiaru sprawiedliwości w okręgu Galizien (Galicja) z 1 sierpnia 1941 r. (Dz. RGG, nr 68, s. 445) i odnosiło się do sądów w dystrykcie Galicja - pojawiło się więc w momencie zwiększenia podmiotowości politycznej w GG ludności ukraińskiej. Oba określenia „sądownictwo polskie” i „sądownictwo nieniemieckie” pochodzą zatem z języka prawnego GG. Po utworzeniu dystryktu
\end{abstract}


dowości polskiej, zostały poddane nadzorowi niemieckich władz okupacyjnych. Oprócz nadzoru administracyjnego sprawowanego przez dystryktowe wydziały sprawiedliwości niemieckie władze sprawowały nad sądownictwem polskim (nieniemieckim) nadzór judykacyjny, realizowany w ramach tzw. prawa sprawdzenia (Nachprüfungsrecht).

Instytucja sprawdzenia prawomocnych orzeczeń sądów polskich (nieniemieckich $)^{5}$ jest jednym z najważniejszych problemów badawczych w obszarze sądownictwa $\mathrm{GG}^{6}$. Do tej pory ze względu na brak dostatecznego materiału źródłowego nie udało się odpowiednio przedstawić istoty tej instytucji ani praktyki jej stosowania.

W ramach przeprowadzonej kwerendy w Archiwum Państwowym w Radomiu odnaleziono trzydzieści pięć orzeczeń (z czego trzy z zakresu prawa karnego) Wyższego Sądu Niemieckiego w Radomiu (dalej jako: WSN w Radomiu) wydanych $w$ ramach procedury prawa sprawdzenia ${ }^{7}$. Orzeczenia te pochodzą z okresu dwóch lat od połowy 1942 r. do połowy 1944 r. Pierwszy wniosek o sprawdzenie prawomocnego orzeczenia sądu polskiego (nieniemieckiego) został złożony do WSN w Radomiu 17 grudnia 1940 r. i był on jedynym, jaki wpłynął do tego sądu w $1940 \mathrm{r}^{8}{ }^{8}$ Wniosek ten został rozpatrzony dopiero w lutym $1942 \mathrm{r}$. W zebranym

Galicja zasadą miało stać się stosowanie nazwy „sądownictwo nieniemieckie” także na określenie sądów funkcjonujących w czterech pierwotnych dystryktach GG. Z przebadanego materiału archiwalnego wynika jednak, że zarówno władze niemieckie, jak i przedstawiciele polskich (nieniemieckich) sądów używali w wewnętrznych pismach, praktycznie do końca okupacji, raz określenia sądy, sądownictwo „polskie”, sędziowie „polscy”, a raz „nieniemieckie”, „nieniemieccy”. Przy czym od mniej więcej połowy 1942 r. określenie „nieniemieckie” stało się częściej stosowaną formą. W niniejszym artykule stosowano więc podwójną nazwę „polskie (nieniemieckie)”, jedynie w miejscach bezpośrednio odnoszących się do przepisów prawnych regulujących sądownictwo „polskie” zastosowano wersję pierwotną nazwy tego pionu sądownictwa.

${ }^{5}$ Podstawowe opracowania na temat sądownictwa polskiego (nieniemieckiego): M. Sworzeń, Sadownictwo polskie w Generalnym Gubernatorstwie, „Prawo i Życie” 1987, nr 40; idem, Sędziowie w podbitym kraju. Oficjalne sadownictwo polskie w Generalnym Gubernatorstwie 1939-1945, „Zeszyty Historyczne” 1999, z. 128; J. Szarycz, Sędziowie i sady w Polsce w latach 1918-1988, Warszawa 1988; A. Wrzyszcz, Nadzór niemiecki nad sadownictwem polskim w Generalnym Gubernatorstwie w latach 1939-1945 [w:] M. Mikołajczyk i in. (red.), O prawie i jego dziejach księgi dwie. Studia ofiarowane Profesorowi Adamowi Lityńskiemu w czterdziestopięciolecie pracy naukowej i siedemdziesięciolecie urodzin, Księga II, Białystok-Katowice 2010; idem, O organizacji okupacyjnego sadownictwa polskiego w Generalnym Gubernatorstwie w latach 1939-1945, „Zeszyty Majdanka" 1992, t. XIV.

${ }^{6}$ A. Wrzyszcz, Okupacyjne sadownictwo niemieckie..., s. 17.

7 Wykaz orzeczeń za poszczególne lata: 1940 - Np 1/40; 1942 - Np 1/42; 3/42; 4/42; 5/42; 6/42; 7/42; 8/42; 9/42; 1943 - Np 1/43; Np 2/43; Np 3/43; Np 4/43; Np 5/43; Np 6/43; Np 8/43; Np 9/43; Np 10/43; Np 11/43; Np 12/43; Np 14/43; Np 15/43; Np 16/43; Nps 17/43; Np 18/43; Np 21/43; Np 22/43; Np 23/43; Np 24/43; 1944 - Np 1/44; Np 3/44; Nps 7/44; Nps 9/44; Np 10/44; Np 11/44. Orzeczenia odnaleziono w: APR, Sąd Apelacyjny w Radomiu 1939-1945, sygn. 8.

${ }^{8}$ A. Wrzyszcz, Okupacyjne sądownictwo niemieckie..., s. 257-258. 
materialne brakuje więc orzeczeń z $1941 \mathrm{r}$. oraz tych wydanych w drugiej połowie 1944 r. Z dużym prawdopodobieństwem można przyjąć, że po sierpniu 1944 r. wpływ spraw, ze względu na zbliżający się front, znacznie zmalał i być może w okresie tym WSN w Radomiu nie rozpatrywał już wniosków o sprawdzenie orzeczeń sądów polskich (nieniemieckich). Dlatego można uznać, że zebrany materiał daje dostateczną podstawę źródłową do przeprowadzenia badań nad orzecznictwem WSN w Radomiu w obszarze sprawdzania prawomocnych orzeczeń sądów polskich (nieniemieckich).

W niniejszym artykule zostanie przedstawiony przebieg postępowania o sprawdzenie prawomocnych orzeczeń sądów polskich (nieniemieckich) przed WSN w Radomiu. Ustalenia wymaga sposób interpretowania przez Wydział Sprawiedliwości w Urzędzie Gubernatora Dystryktu Radomskiego, niezbędnej do wszczęcia postępowania, przesłanki ,interesu publicznego". Wskazane zostaną także rodzaje spraw cywilnych i karnych rozpatrywanych w ramach tej procedury. Opracowanie ma zatem służyć odpowiedzi na pytanie, jaka była rola instytucji prawa sprawdzenia w ustroju sądownictwa w GG.

\section{PRAWO SPRAWDZENIA PRAWOMOCNYCH ORZECZEŃ SĄDÓW POLSKICH (NIENIEMIECKICH) W GENERALNYM GUBERNATORSTWIE}

Pierwszym aktem prawnym odnoszącym się do sądownictwa w GG było rozporządzenie o odbudowie wymiaru sprawiedliwości w Generalnym Gubernatorstwie z dnia 26 października 1939 r. ${ }^{9}$ Regulowało ono podstawowe zasady systemu sądownictwa, które miały zostać uszczegółowione w późniejszych rozporządzeniach. Rozporządzenie o odbudowie wymiaru sprawiedliwości z 26 października 1939 r., oprócz wprowadzenia dualistycznego systemu sądownictwa powszechnego w GG, określało zadania sądownictwa niemieckiego, prawo sprawdzenia wyroków sądów polskich przez sądy niemieckie oraz definiowało moment rozpoczęcia funkcjonowania sądownictwa na okres po ostatecznym ustaleniu granic obszaru GG.

W Generalnym Gubernatorstwie utworzony został dualistyczny model sądownictwa powszechnego. Zadania sądownictwa niemieckiego zostały określone jako: „ściganie zamachów na bezpieczeństwo i autorytet Rzeszy i Narodu Niemieckiego, oraz życie, zdrowie i własności obywateli narodowości niemieckiej" ${ }^{\prime 10}$. Organizacja i funkcjonowanie sądownictwa niemieckiego oparte zostały na dwóch rozporządze-

${ }^{9}$ Rozporządzenie o odbudowie wymiaru sprawiedliwości w Generalnym Gubernatorstwie z dnia 26 października 1939 r. (Dziennik Rozporządzeń Generalnego Gubernatora dla okupowanych polskich obszarów [dalej: Dz. RGGOP], nr 1, s. 4).

${ }^{10}$ Ibidem, $\S 2$ ust. 1. 
niach: o sądach specjalnych w Generalnym Gubernatorstwie z 15 listopada 1939 r. ${ }^{11}$ i o sądownictwie niemieckim w Generalnym Gubernatorstwie z 19 lutego 1940 r. ${ }^{12}$ Natomiast sądownictwo polskie działało głównie na podstawie rozporządzenia z 19 lutego 1940 r. o sądownictwie polskim w Generalnym Gubernatorstwie ${ }^{13}$. Istotne znaczenie miało także rozporządzenie z 19 lutego 1940 r. o przejściu spraw prawnych w sądownictwie niemieckim i polskim ${ }^{14}$. Powyższe pięć rozporządzeń generalnego gubernatora stanowiło trzon regulacji prawnych sądownictwa podlegającego władzom GG, ale nie były jedynymi aktami prawnymi, które dotyczyły tej materiii ${ }^{15}$.

Druga ważna zasada, wprowadzona przez rozporządzenie o odbudowie wymiaru sprawiedliwości w Generalnym Gubernatorstwie z 26 października 1939 r., umożliwiła poddanie sprawdzeniu prawomocnych orzeczeń sądów polskich ${ }^{16}$. Była to jednak bardzo ogólna regulacja, która stanowiła jedynie zapowiedź, że w tworzonym systemie sądownictwa w GG sędzia niemiecki będzie miał możliwość nadzorowania wyroków polskich sądów i w przypadku ich uchylenia - przekazania sprawy do sądownictwa niemieckiego. Dokładne uregulowanie kwestii sprawdzania prawomocnych orzeczeń polskich sądów znalazło się w rozporządzeniu o sądownictwie polskim z 19 lutego $1940 \mathrm{r}$.

Prawo sprawdzenia uregulowane zostało w rozdziale $\mathrm{V}$ rozporządzenia o sądownictwie polskim z 19 lutego 1940 r., w $\S$ 16-18. Zgodnie z tymi przepisami sprawdzenie prawomocnego orzeczenia sądu polskiego możliwe było, jeżeli wskazywał na to interes publiczny. Wniosek o sprawdzenie wyroku sądu polskiego mógł wnieść wyłącznie kierownik wydziału sprawiedliwości w urzędzie gubernatora dystryktu. Termin na wniesienie wniosku do wyższego sądu niemieckiego wynosił 6 miesięcy od momentu uprawomocnienia się sprawdzanego orzeczenia.

W przypadku orzeczeń, które były prawomocne w momencie wejścia w życie rozporządzenia o sądownictwie polskim z 19 lutego 1940 r., możliwe było poddanie ich sprawdzeniu, jeżeli uprawomocniły się po 31 lipca 1938 r. W takim wypadku

${ }^{11}$ Rozporządzenie o sądach specjalnych w Generalnym Gubernatorstwie z dnia 15 listopada 1939 r. (Dz. RGGOP, nr 6, s. 34-36).

12 Rozporządzenie o sądownictwie niemieckim w Generalnym Gubernatorstwie z dnia 19 lutego 1940 r. (Dz. RGGOP, cz. I, nr 13, s. 57-63).

${ }_{13}$ Rozporządzenie o sądownictwie polskim w Generalnym Gubernatorstwie z dnia 19 lutego 1940 r. (Dz. RGGOP, cz. I, nr 13, s. 64-68).

${ }^{14}$ Rozporządzenie o przejściu spraw prawnych w sądownictwie niemieckim i polskim z dnia 19 lutego 1940 r. (Dz. RGGOP, cz. I, nr 13, s. 68-71).

15 Wykaz innych istotnych rozporządzeń dotyczących sądownictwa w GG: A. Wrzyszcz, Nadzór Hansa Franka nad sądownictwem w Generalnym Gubernatorstwie w latach 1939-1945, „Miscellanea Historico-Iuridica” 2015, t. XIV, z. 2, s. 378.

${ }^{16}$ Rozporządzenie o odbudowie wymiaru sprawiedliwości z 26 października 1939 r., $§ 3$. 
sześciomiesięczny termin na wniesienie wniosku biegł od momentu wejścia w życie rozporządzenia. Możliwe było także, w przypadku podejrzenia naruszenia orzeczeniem interesu narodu niemieckiego, sprawdzenie tych, które zostały wydane przed 31 lipca 1938 r. Niezbędne było do tego jednak zarządzenie kierownika Wydziału Sprawiedliwości w Urzędzie Generalnego Gubernatora ${ }^{17}$.

Wyższy sąd niemiecki mógł potwierdzić rozstrzygnięcie, jakiego dokonał polski (nieniemiecki) sąd, znieść orzeczenie i przekazać sprawę do rozstrzygnięcia sądowi niemieckiemu (działo się tak przede wszystkim w sytuacjach, gdy niezbędne było przeprowadzenie postępowania dowodowego ${ }^{18}$ ) albo sam orzec w sprawie. Jeżeli sąd zdecydował o przekazaniu sprawy sądowi niemieckiemu, orzekać miał sąd właściwy miejscowo dla sprawy, w sprawach karnych sprawy przekazywane były właściwemu miejscowo sądowi specjalnemu. Jeżeli sprawdzane orzeczenie było wyrokiem, wyższy sąd niemiecki orzekał wyrokiem po przeprowadzeniu ustnej rozprawy. W innych przypadkach decyzja miała być podejmowana w formie postanowienia, po przeprowadzeniu postępowania w formie wybranej przez wyższy sąd niemiecki, z uwagi na wagę sprawy ${ }^{19}$.

Problemem natury formalnej było to, jakie prawo miało być stosowane do oceny orzeczeń w ramach instytucji prawa sprawdzenia. Niemieckie władze administracyjne wymagały, aby ocena polskich orzeczeń dokonywana była w odniesieniu do prawa niemieckiego ${ }^{20}$. Do problematyki tej odniósł się Władysław Wolter: „Dla każdego prawnika jest rzeczą zupełnie jasną, że jakakolwiek kontrola może odbywać się tylko przy użyciu tych samych norm. Tymczasem wydział sprawiedliwości domagał się, by sądy niemieckie poddawały kontroli wyroki sądów polskich przy użyciu prawa niemieckiego. Znaczy to, że sąd niemiecki miał według niemieckiego prawa kontrolować, czy sąd polski wydał słuszny wyrok według polskiego prawa. Był to tak oczywisty absurd logiczny, że nawet sędziowie niemieccy nie byli w stanie odmówić racji przeciwnym wywodom polskich obrońców”21. Ostatecznie wypracowano sposób postępowania, w ramach którego wyższy sąd niemiecki badał, czy orzeczenie jest zgodne z obowiązującym wyrokujący sąd prawem, a następnie

17 Rozporządzenie o sądownictwie polskim z 19 lutego 1940 r., §§ 16-18.

${ }_{18}$ Archiwum Akt Nowych (dalej jako: AAN), Ministerstwo Informacji i Dokumentacji Rządu RP (emigracyjnego) w Londynie, sygn. 105, k. 264. Opracowanie K. Willego „Wymiar sprawiedliwości w Generalnym Gubernatorstwie".

19 Rozporządzenie o sądownictwie polskim z 19 lutego 1940 r., § 17.

${ }^{20}$ M. Waligórski, Działalność najeźdźcy hitlerowskiego $w$ dziedzinie jego funkcji ustawodawcy na terenie sadownictwa cywilnego [w:] Ekspertyzy i orzeczenia przed Najwyższym Trybunałem Narodowym, wybór i przygotowanie do publikacji Cz. Pilichowski, t. II, Warszawa 1979, s. 379.

${ }^{21}$ A. Wrzyszcz, Okupacyjne sądownictwo niemieckie..., s. 386-387. 
czy jest zgodne z „zasadniczymi poglądami niemiecko-prawnymi”"22, czy też „niemieckim pojmowaniem prawa"23.

Wątpliwości mogła budzić także pozycja wyższego sądu niemieckiego w odniesieniu do sądownictwa polskiego (nieniemieckiego). Czy skoro wyższe sądy niemieckie sprawowały nadzór judykacyjny nad orzecznictwem sądów polskich (nieniemieckich), można było uznać, że wchodziły także w struktury sądownictwa polskiego (nieniemieckiego)? W tej sprawie wyraźnie wypowiedział się Kurt Wille, twierdząc, że nie można traktować wyższych sądów niemieckich jako instancji usytuowanej w pionie sądownictwa polskiego (nieniemieckiego). Kierownik GWS całkowicie odrzucił pogląd, że wyższy sąd niemiecki może być niejako instancyjnym „przedłużeniem” sądownictwa polskiego ${ }^{24}$.

Podziemny kodeks etyki adwokatury wyraźnie zakazywał zwracania się do władz niemieckich z wnioskiem o wzruszenie orzeczeń sądów polskich (nieniemieckich). W Biuletynie Informacyjnym z 19 maja 1940 r. zamieszczony był artykuł Dekalog Obywatelski, w którym pisano: „Do jakichkolwiek sporów między Polakami nie wolno używać wrogów ani wrogom się skarżyć. Podłością jest pisanie zażaleń, a tym bardziej donosów na Polaka do wrogiej władzy, której pycha i której pogarda dla Polski w ten sposób rośnie"25.

Anonimowy autor pracy dotyczącej sądownictwa w Generalnym Gubernatorstwie, sporządzonej dla Ministerstwa Sprawiedliwości w Rządzie Emigracyjnym RP w Londynie, opisywał, że sądy niemieckie z prawa sprawdzenia prawomocnych orzeczeń korzystały „oględnie"26. W pracy tej przywołany został przypadek z apelacji warszawskiej, w którym wyższy sąd niemiecki uznał za stan sprzeczny z poczuciem prawnym narodu niemieckiego odroczenie wykonania eksmisji Żyda z domu będącego własnością osoby podającej się za przynależną do narodu niemieckiego. Inny podany w tej pracy przypadek dotyczył wniosku złożonego przez polskiego adwokata o sprawdzenie prawomocnego wyroku polskiego (nieniemieckiego) sądu II instancji. Adwokat twierdził, że polscy sędziowie rozpatrzyli sprawę

${ }^{22}$ AAN, Ministerstwo Informacji i Dokumentacji Rządu RP (emigracyjnego) w Londynie, sygn. 105, k. 264. Opracowanie K. Willego „Wymiar sprawiedliwości w Generalnym Gubernatorstwie”.

${ }^{23}$ Archiwum Państwowe w Lublinie, Urząd Okręgu Lublin, sygn. 914, k. 185-189. Pismo z 24 marca 1942 r. kierownika GWS do Wydziału Sprawiedliwości w Urzędzie Gubernatora Dystryktu Krakowskiego w sprawie sprawadzania polskich wyroków.

${ }^{24}$ Ibidem, k. 185-189.

${ }_{25}$ M. Sworzeń, Sędziowie w podbitym kraju..., s. 44-45.

${ }^{26}$ Potwierdza to Ludwig Fischer, który w jednym ze swoich raportów zanotował: „Ludność polska coraz częściej zwraca się o rewizję prawomocnych wyroków sądów polskich. Jednakże kierownik Wydziału Sprawiedliwości tylko w dwóch przypadkach zalecił Niemieckiemu Sądowi Wyższemu rewizję wyroku". Raporty Ludwiga Fischera gubernatora dystryktu warszawskiego 1939-1944, wybór i opracowanie K. Dunin-Wąsowicz, M. Getter, J. Kaźmierski, J. Kaźmierska, Warszawa 1987, s. 234. 
nie dość starannie i wydali błędny wyrok. Władze niemieckie nakazały przekazanie im akt sprawy ${ }^{27}$. Nie wiadomo, czy w tej konkretnej sprawie doszło do wszczęcia procedury sprawdzenia.

Marian Sworzeń przywołał przypadki zmiany prawomocnych wyroków sądów polskich (nieniemieckich) zarówno na rzecz zaostrzenia wyroków karnych, jak i ich złagodzenia. Jako przykład podaje on sprawę karną, która dotyczyła zbrodni na członku rodziny - w sprawie tej wyższy sąd niemiecki złagodził prawomocny wyrok polskiego sądu. Odebrane to zostało jako dowód wyrozumiałości władz niemieckich dla pospolitych przestępców ${ }^{28}$.

\section{PRZEBIEG POSTĘPOWAŃ O SPRAWDZENIE PRAWOMOCNYCH ORZECZEŃ SĄDÓW POLSKICH (NIENIEMIECKICH) PRZED WYŻSZYM SĄDEM NIEMIECKIM W RADOMIU}

Postępowanie o sprawdzenie prawomocnych orzeczeń sądów polskich (nieniemieckich) inicjowane było poprzez złożenie przez kierownika dystryktowego wydziału sprawiedliwości wniosku do wyższego sądu niemieckiego. Wniosek taki zawierał wskazanie orzeczenia, które miało zostać sprawdzone, podstawę prawną złożenia wniosku oraz uzasadnienie. W uzasadnieniu wskazywano na wystąpienie przesłanek niezbędnych do wszczęcia postępowania sprawdzającego: prawomocność orzeczenia sądu polskiego (nieniemieckiego), zachowanie terminu 6 miesięcy od uprawomocnienia się orzeczenia, istnienie interesu publicznego we wszczęciu postępowania o prawo sprawdzenia. Najważniejszym elementem wniosku było uzasadnienie istnienia interesu publicznego, dlatego kwestiom tym poświęcano najwięcej miejsca. Kierownik dystryktowego wydziału sprawiedliwości we wniosku powoływał się także na skierowane do niego pisma od innych organów władzy niemieckiej, które inicjowały złożenie wniosku ${ }^{29}$. Pisma tego typu były w niektórych przypadkach dołączane do wniosku ${ }^{30}$. Do każdego wniosku dołączano też akta postępowań toczących się przed sądami polskimi (nieniemieckimi) wraz z thumaczeniami wyroków (postanowień) na język niemiecki.

${ }^{27}$ AAN, Ministerstwo Sprawiedliwości Rządu Emigracyjnego RP w Londynie, sygn. 86, k. 45. Sądownictwo, palestra i notariat w czasie wojny.

${ }^{28}$ M. Sworzeń, Sędziowie w podbitym kraju..., s. 44.

${ }^{29}$ Archiwum Państwowe w Radomiu, Niemiecki Sąd Wyższy w Radomiu, sygn. 2, k. 4-5. Wniosek kierownika Wydziału Sprawiedliwości w Urzędzie Gubernatora Dystryktu Radomskiego o sprawdzenie prawomocnego wyroku Sądu Okręgowego w Radomiu w sprawie Ca 670/42 z 23 lutego $1943 \mathrm{r}$.

${ }^{30}$ APR, Sąd Apelacyjny w Radomiu 1939-1945, sygn. 8, k. 84. Wyrok Wyższego Sądu Niemieckiego w Radomiu z 23 czerwca 1943 r. w sprawie cywilnej Np 4/43. 
Po wniesieniu wniosku WSN w Radomiu badał kwestie formalne, czy wniosek został złożony we właściwym terminie, czy wzruszone orzeczenie stało się prawomocne oraz czy zostało stwierdzone istnienie interesu publicznego w sprawdzeniu prawomocnego orzeczenia sądu polskiego (nieniemieckiego). WSN w Radomiu w swoich wyrokach podkreślał, że kierownik dystryktowego wydziału sprawiedliwości był wyłącznie właściwy do stwierdzenia istnienia interesu publicznego w sprawdzeniu prawomocnych wyroków sądów polskich (nieniemieckich), dlatego nie kwestionowano jego ustaleń ${ }^{31}$. Wyższy sąd niemiecki badał jedynie, czy we wniosku stwierdzono istnienie interesu publicznego do wszczęcia postępowania sprawdzającego.

Odpisy wniosku były doręczane stronom postępowania. Strony miały następnie prawo do złożenia pism przygotowawczych, w których mogły wypowiedzieć się w przedmiocie wniosku o sprawdzenie oraz zawrzeć własne żądania i wnioski. Do pism przygotowawczych w celu poparcia swoich twierdzeń dołączano np. tezy prawne uchwalone przez sądy apelacyjne. Również na ustnej rozprawie strony mogły przedstawić swoje wnioski. W przypadku gdy strona lub strony nie przedstawiły żadnych pism i wniosków, WSN w Radomiu ustalał stanowiska stron na podstawie akt sądów polskich (nieniemieckich) ${ }^{32}$. Na trzydzieści pięć przeanalizowanych postępowań prowadzonych przez WSN w Radomiu tylko w pięciu przypadkach żadna ze stron nie zajęła stanowiska w sprawie poprzez złożenie pisma przygotowawczego lub wniosku na rozprawie ustnej.

Strony w postępowaniach o sprawdzenie prawomocnych orzeczeń sądów polskich (nieniemieckich) mogły być reprezentowane przez pełnomocników procesowych. W ponad połowie z przeanalizowanych spraw co najmniej jedna strona miała pełnomocnika procesowego (17 - brak pełnomocnika; 10 - pełnomocnik jednej ze stron; 8 - pełnomocnicy obu stron). Niewątpliwie na możliwość ustanowienia pełnomocnika wpływały środki finansowe, jakimi dysponowały strony. W niektórych sprawach strony ustanowiły dwóch pełnomocników, polskiego adwokata, który najprawdopodobniej znał sprawę i prowadził ją przed sądami polskimi (nieniemieckimi), oraz adwokata niemieckiego, który znał niemieckie postępowanie i przebieg postępowania przed wyższym sądem niemieckim ${ }^{33}$. Przed WSN w Radomiu w postępowaniach o prawo sprawdzenia występowali adwokaci niemieccy (adwokat Heinz Schmitz z Radomia, adwokat dr Villinger z Radomia).

${ }^{31}$ APR, Sąd Apelacyjny w Radomiu 1939-1945, sygn. 8, k. 155. Wyrok Wyższego Sądu Niemieckiego w Radomiu z 22 marca 1944 r. w sprawie cywilnej Np 3/44.

${ }^{32}$ APR, Sąd Apelacyjny w Radomiu 1939-1945, sygn. 8, k. 66. Wyrok Wyższego Sądu Niemieckiego w Radomiu z 22 marca 1944 r. w sprawie cywilnej Np 9/43.

${ }_{33}$ Taki przypadek miał miejsce w sprawie o sygnaturze Np 23/43 - strona pozwana była bowiem reprezentowana przez adwokata Heinza Schmitza z Radomia oraz adwokata Piotr Ławacza z Końskich. 
W większości spraw strony korzystały jednak z usług adwokatów, a w jednej sprawie także obrońcy sądowego, narodowości polskiej. Przed WSN w Radomiu występowali: adwokat Stanisław Berger z Radomia, adwokat Zdzisław Lindeman z Radomia, adwokat Edmund Masiak z Radomia ${ }^{34}$, adwokat Jan Filipiak z Radomia, adwokat Maria Gajewiczowa z Radomia, adwokat Wacław Walkiewicz z Końskich, adwokat Piotr Ławacz z Końskich, adwokat Dymitr Mirman z Częstochowy, adwokat Jan Gruszczyński z Częstochowy oraz obrońca sądowy Feliks Bohdan Cielecki z Sandomierza ${ }^{35}$.

Pierwszym etapem postępowań WSN w Radomiu było merytoryczne sprawdzenie prawomocnych orzeczeń sądów polskich (nieniemieckich). Orzeczenia te były oceniane pod kątem prawa obowiązującego w Generalnym Gubernatorstwie, a więc przede wszystkim przedwojennego polskiego prawa zmienionego przez ustawodawstwo niemieckie w GG. Sędziowie WSN w Radomiu w sprawach, które miały wyjątkowy charakter i wymagały przeprowadzenia dokładnej interpretacji prawa, uzasadniali swoje orzeczenia poprzez porównania polskich instytucji prawnych do analogicznych obowiązujących w Rzeszy (,starej Rzeszy”) oraz odnosząc się do niemieckich przedstawicieli doktryny ${ }^{36}$. Wynikało to być może z lepszej znajomości tego prawa przez niemieckich sędziów, którym w ten sposób, poprzez odniesienie się do instytucji prawnych, które lepiej znali, łatwiej było uzasadnić podjęte decyzje. Ostatecznie jednak wyrok oceniany był w świetle tego samego prawa, na podstawie którego został wydany.

Wyższy sąd niemiecki zgodnie z $§ 17$ ust. 2 rozporządzenia o sądownictwie polskim z 19 lutego 1940 r. mógł potwierdzić sprawdzane orzeczenie sądu polskiego (nieniemieckiego) albo je znieśćc ${ }^{37}$. W analizowanych trzydziestu pięciu sprawach prowadzonych przez WSN w Radomiu we wszystkich doszło do uchylenia orzeczeń sądów polskich (nieniemieckich), żadne orzeczenie nie zostało zatwierdzone. WSN w Radomiu mógł uchylić cały wyrok albo tylko jego części.

${ }^{34}$ Adwokat Edmund Masiak w okresie okupacji był w więzieniu na Zamku w Lublinie od 22 listopada 1939 r. do 15 lutego 1940 r. Powodem zatrzymania przez Gestapo i uwięzienie był domniemany zarzut uczestnictwa w tzw. krwawej niedzieli w Bydgoszczy. Po wyjściu z więzienia od marca 1940 r. do listopada 1941 r. pracował jako sędzia w Radomiu. Od 7 listopada 1941 r. wykonywał zawód adwokata w dystrykcie radomskim. Po wojnie był pierwszym pochodzącym z wyboru dziekanem Rady Adwokackiej w Gdańsku w latach 1956-1959. Za: K. Golec, Adw. Edmund MasiakCzwarty Dziekan Pomorskiej Izby Adwokackiej, „Gdański Kwartalnik Adwokacki” 2017, nr 44, s. 5.

${ }^{35}$ Biogramy części z wymienionych adwokatów: S. Piątkowski, Historia adwokatury radomskiej, Radom 2018.

${ }^{36}$ APR, Sąd Apelacyjny w Radomiu 193921945, sygn. 8, k. 73. Wyrok Wyższego Sądu Niemieckiego w Radomiu z 23 czerwca 1943 r. w sprawie cywilnej Np 5/43. W uzasadnieniu do tego wyroku znajdują się takie stwierdzenia, jak: „Ani niemiecka, ani polska procedura cywilna nie wymieniają prawomocności orzeczenia sądowego jako zarzutu procesowego”; „Obowiązuje to także i w polskim prawie".

${ }^{37}$ Rozporządzenie o sądownictwie polskim z 19 lutego 1940 r., § 17 ust. 2. 
W przypadku uchylenia orzeczenia sądu polskiego (nieniemieckiego) wyższy sąd niemiecki mógł albo przekazać sprawę sądownictwu niemieckiemu (w sprawach cywilnych właściwemu sądowi niemieckiemu, w sprawach karnych właściwemu sądowi specjalnemu [po połączeniu sądów specjalnych z sądami niemieckimi także sprawy karne były przekazywane właściwym sądom niemieckim] ${ }^{38}$ ), albo sam merytorycznie rozstrzygnąć sprawę. Jeżeli wyższy sąd niemiecki zdecydował się sam rozstrzygnąc sprawę, która dotyczyła sprawdzenia wyroku, to rozstrzygał ją po przeprowadzeniu ustnej rozprawy również wyrokiem, odpowiednio w przypadku sprawdzenia postanowienia - rozstrzygał postanowieniem. W odniesieniu do analizowanego materiału tylko cztery orzeczenia sprawdzane przez WSN w Radomiu były postanowieniami sądów polskich (nieniemieckich), a aż trzydzieści jeden było wyrokami. W trzech przypadkach postanowienia te dotyczyły zabezpieczenia przedmiotu sporu i nie miały charakteru postanowień kończących postępowanie w sprawie. Wynika z tego, że prawo do sprawdzenia przysługiwało wobec wszystkich „rozstrzygnięć” sądu polskiego (nieniemieckiego), również wobec postanowień (przedstanowczych) niekończących postępowania w sprawie.

WSN w Radomiu na trzydzieści pięć analizowanych spraw w ośmiu przypadkach (siedem spraw cywilnych, jedna sprawa karna) przekazał sprawę sądownictwu niemieckiemu, a w pozostałych - sam rozstrzygnął sprawę. Sądownictwu niemieckiemu przekazane zostały te sprawy, w których konieczne było przeprowadzenie dalszych dowodów. WSN w Radomiu uzasadniał np., że „Wyższy Sąd Niemiecki wydałby wyrok sam co do rozstrzygnięcia w bezpośrednim związku z postępowaniem dotyczącym sprawdzenia, gdyby spór był już dojrzały do rozstrzygnięcia" ${ }^{39}$. Tendencja była więc taka, że WSN w Radomiu sam starał się merytorycznie rozstrzygać sprawy, w których uchylił orzeczenia. Do sądów niemieckich przekazywano zaś te sprawy, których rozpatrzenie za bardzo obciążałoby pracą wyższy sąd niemiecki.

W przypadku merytorycznego rozstrzygania spraw WSN w Radomiu w sprawach karnych stosował prawo materialne obowiązujące w „Altreich” oraz niemieckie prawo procesowe ${ }^{40}$. Odmiennie wyglądała ta kwestia w sprawach cywilnych - wówczas stosowano bowiem materialne prawo obowiązujące w GG (polskie przedwojenne prawo zmienione przez ustawodawstwo niemieckie w GG), samo postępowanie natomiast zgodnie z $\S 25$ rozporządzenia o sądownictwie niemieckim z 19 lutego 1940 r. prowadzone było na podstawie niemieckich przepi-

${ }^{38}$ Ibidem, $\S 17$ ust. 3.

39 APR, Sąd Apelacyjny w Radomiu 1939-1945, sygn. 8, k. 122. Wyrok Wyższego Sądu Niemieckiego w Radomiu z 29 września 1943 r. w sprawie Np 14/43.

${ }^{40}$ Wynikało to z przepisów $\S \S 8$ i 9 rozporządzenia o sądownictwie niemieckim z 19 lutego $1940 \mathrm{r}$. 
sów procesowych ${ }^{41}$. Z tego powodu WSN w Radomiu musiał rozstrzygać kwestie prawne, np. czy przepis $\S 864$ BGB (analogiczny do art. $390 \mathrm{kpc} \mathrm{z} 1930 \mathrm{r}^{42}$ ) mimo umieszczenia go $\mathrm{w}$ prawie materialnym miał charakter przepisu procesowego i powinien być zastosowany.

WSN w Radomiu w merytorycznie rozstrzyganych sprawach mógł przeprowadzić postępowanie dowodowe. Jednak ze wskazanych przyczyn, aby nie obciążać sądu, raczej nie przeprowadzano nowych dowodów. Opierano się na ustaleniach poczynionych przez sądy polskie (nieniemieckie). W dwóch sprawach karnych przesłuchano skazanych na rozprawie, w jednej z nich przesłuchano też świadków (pokrzywdzonego, ojca pokrzywdzonego i przełożonego skazanego) ${ }^{43}$. W kilku sprawach cywilnych, na podstawie postanowień dowodowych, dopuszczono dowód polegający na zasięgnięciu urzędowej informacji od organów administracyjnych (starostowie, agronomowie powiatowi, wójtowie). Chodziło o wskazanie, komu WSN w Radomiu powinien przyznać całą nieruchomość ${ }^{44}$, albo np. o ustalenie cen nieruchomości ${ }^{45}$.

Wyższe sądy niemieckie orzekały w składzie trzech sędziów ${ }^{46}$. WSN w Radomiu w większości spraw o sprawdzenie prawomocnych orzeczeń sądów polskich (nieniemieckich) orzekał w składzie: jako przewodniczący dr Hans Burmeister (w randze Landgerichtsdirektor), dr Gerhard Kubowitz (w randze Oberlandesgerichtsrat), Paul Betthausen (w randze beauftragter Richter) ${ }^{47}$. W dwóch sprawach w składzie orzekającym zasiadał sędzia Ebert, przewodniczący Sądu Specjalnego w Radomiu (raz za sędziego Burmeistera, przewodniczył wtedy Kubowitz; raz za sędziego Betthausena), w dwóch sprawach orzekał także sędzia Benker (dwukrotnie za sędziego Kubowitza). W sprawach karnych jako prokuratorzy występowali: nadprokurator Blum oraz prokurator z polecenia Ballat.

Odpisy orzeczeń WSN w Radomiu wydanych w ramach procedury prawa sprawdzenia były przekazywane Witoldowi Prądzyńskiemu, kierownikowi Sądu Apelacyjnego w Radomiu. Tłumaczenia odpisów kierownik przekazywał do zapoznania się przewodniczącym wydziałów cywilnego i karnego w Sądzie Apelacyjnym w Radomiu oraz kierownikom sądów okręgowych w Kielcach, Piotrkowie

${ }^{41}$ Rozporządzenie o sądownictwie niemieckim z 19 lutego 1940 r., § 25 ust. 1.

${ }^{42}$ Rozporządzenie Prezydenta Rzeczypospolitej z 29 listopada 1930 r. - Kodeks postępowania cywilnego (t.j. Dz. U. 1932, Nr 112, poz. 934).

43 Chodzi o sprawę o sygn. Nps 7/44.

${ }^{44}$ APR, Sąd Apelacyjny w Radomiu 1939-1945, sygn. 8, k. 42. Wyrok Wyższego Sądu Niemieckiego w Radomiu z 21 marca 1943 r. w sprawie cywilnej Np 7/42.

45 APR, Sąd Apelacyjny w Radomiu 1939-1945, sygn. 8, k. 23. Wyrok Wyższego Sądu Niemieckiego w Radomiu z 27 lutego 1942 r. w sprawie cywilnej Np 6/42.

${ }^{46}$ Rozporządzenie o sądownictwie niemieckim z 19 lutego 1940 r., § 2.

${ }^{47}$ APR, Niemiecki Sąd Wyższy w Radomiu, sygn. 5, k. 5. Spis pracowników sądu Deutsches Obergericht w Radomiu z roku 1944 otrzymujących karty żywnościowe. 
i Radomiu ${ }^{48}$. W ten sposób o wydanych orzeczeniach informowane były także sądy polskie (nieniemieckie) w dystrykcie radomskim.

\section{SPRAWY KARNE}

Z zakresu prawa karnego odnaleziono trzy sprawy prowadzone przez Wyższy Sąd Niemiecki w Radomiu w ramach postępowania o sprawdzenie prawomocnych orzeczeń sądów polskich (nieniemieckich). Sprawy karne prowadzone pod sygnaturą „Nps” były najprawdopodobniej wpisywane do tego samego repertorium co sprawy cywilne. Wskazuje na to zachowana ciągłość numeracji w obu rodzajach spraw.

Pierwsza ze spraw, wpisana do repertorium pod sygnaturą Nps 17/43, dotyczyła wyroku wydanego przez Sąd Grodzki w Końskich ${ }^{49}$ w sprawie kradzieży. W omawianej sprawie skazana Z.K. ukradła przyjaciółce kartę zapotrzebowania na parę damskich trzewików, wystawioną przez starostę (Stadthauptmanna) w Końskich, po czym na karcie wyskrobała dane właścicielki karty zapotrzebowania i w odpowiedniej rubryce wpisała zmyślone dane. Z.K. wysłała do sklepu własną matkę, która nie była świadoma uczestnictwa w przestępstwie. Kierownik sklepu firmy Bata w Końskich rozpoznał zmianę nazwiska na karcie zapotrzebowania. Przeciwko Z.K. i jej matce wszczęto postępowanie karne w Sądzie Grodzkim w Końskich, który skazał Z.K. na tydzień aresztu za kradzież, uniewinniając jej matkę. Wyrok uprawomocnił się.

W niniejszej sprawie do WSN w Radomiu wniosek o sprawdzenie wyroku wniósł kierownik Wydziału Sprawiedliwości w Urzędzie Gubernatora Dystryktu Radomskiego. Wyrok został uznany za błędny, ponieważ Sąd Grodzki w Końskich przyjął błędną kwalifikację prawną czynu, Z.K. miała bowiem dopuścić się nie tylko kradzieży, ale także sfałszowania dokumentu oraz naruszyć przepisy ordynacji karnej o regulacji spożycia. Za obrazę interesu publicznego uznano dodatkowo niski wymiar kary, nieodpowiadający ciężarowi gatunkowemu przestępstwa.

Wyższy Sąd Niemiecki w Radomiu uchylił wyrok Sądu Grodzkiego w Końskich w zakresie, w jakim dotyczył on Z.K., w pozostałym zakresie wyrok został zatwierdzony. Po merytorycznym rozpoznaniu sprawy przez WSN w Radomiu Z.K. została skazana na trzy miesiące więzienia. W uzasadnieniu WSN stwierdzono, że wystawiona przez starostę w Końskich karta zapotrzebowania na obuwie jest dokumentem w rozumieniu prawa karnego. Z.K. w celu wprowadzenia w błąd

${ }^{48}$ APR, Sąd Apelacyjny w Radomiu 1939-1945, sygn. 8, k. 92. Pismo przewodnie kierownika Sądu Apelacyjnego w Radomiu z 7 lutego 1944 r.

49 APR, Sąd Apelacyjny w Radomiu 1939-1945, sygn. 8, k. 93-94; 100-102. Wyrok Wyższego Sądu Niemieckiego w Radomiu z 10 grudnia 1943 r. w sprawie karnej Nps 17/43. 
sfałszowała prawdziwy dokument, co nosiło znamiona przestępstwa określonego przez art. $187 \mathrm{kk} \mathrm{z} 1932$ r. ${ }^{50}$ WSN uznał, że ze względów celowościowych skorzysta z przysługującego mu prawa do merytorycznego rozpoznania sprawy. Sprawa została rozpoznana w myśl przepisów niemieckich. Z.K. uznano za winną kradzieży określonej przez $§ 242$ kodeksu karnego Rzeszy oraz przestępstwa sfałszowania dokumentu uregulowanego w $\S 267$ kodeksu karnego Rzeszy w brzmieniu rozporządzenia z 29 maja 1943 r., które pomimo wejścia w życia po dokonaniu przestępstwa WSN w Radomiu uznał za łagodniejszy dla skazanej. WSN w Radomiu zgodnie z wnioskiem DWS uznał, że Z.K. dopuściła się także naruszenia $§ 2$ ordynacji karnej regulującej spożycie, poprzez to, że usiłowała wykorzystać dla siebie nieprzysługującą jej kartę uprawniającą do zakupu. Przy wymierzaniu kary jako okoliczność łagodzącą przyjęto, że skazana znajdowała się w trudnym położeniu materialnym, natomiast jako okoliczność obciążającą - fakt, że czyn został dokonany na szkodę przyjaciółki, która także znajdowała się w trudnym położeniu materialnym, oraz znaczna doza zuchwalstwa w sfałszowaniu dokumentów. WSN pozytywnie ocenił uniewinnienie przez Sąd Grodzki w Końskich matki Z.K., która jako analfabetka nie była w stanie poznać, że przekazana jej karta zapotrzebowania była sfałszowana.

Drugi wyrok w sprawie karnej wydany przez WSN w Radomiu w ramach prawa sprawdzenia dotyczył wyroku Sądu Apelacyjnego w Radomiu wydanego w sprawie o uszkodzenie ciała ${ }^{51}$. Po zakończeniu likwidacji getta w Ostrowcu kierownik niemieckiej Schutzpolizei w tej miejscowości „użył” - a więc zapewne wydał rozkaz - policjantów granatowych oraz nadzorców ostrowieckiego aresztu miejskiego do zwalczania rozpowszechniającej się w znacznym zakresie kradzieży w dawnej dzielnicy żydowskiej. Funkcjonariusze policji granatowej oraz nadzorcy aresztu otrzymali polecenie bezwzględnego występowania przeciwko wszystkim przestępcom, także młodocianym, oraz uzyskali zgodę na użycie w razie potrzeby broni palnej. Do tego zadania został oddelegowany zatrudniony w areszcie miejskim skazany J.Z. W trakcie obchodu na terenie wysiedlonego getta, na którym nie mogły znajdować się żadne osoby cywilne, umundurowany J.Z. przy jednym z domów na ostrowieckim rynku ujrzał dwóch rąbiących drewno chłopców. Na jego zawołanie jeden z nich zaczął uciekać, więc by go zatrzymać, J.Z. rzucił w kierunku uciekającego chłopca dachówkę z wystającym gwoździem. Dachówka uderzyła chłopca w nogę pod prawym kolanem, co spowodowało mocno krwawiącą ranę. Zraniony chłopiec musiał w konsekwencji 3 tygodnie przeleżeć w łóżku, a przez kolejne 6 tygodni utykał na zranioną nogę. Sąd Okręgowy w Radomiu skazał J.Z. na 2 tygodnie aresztu za uszkodzenie ciała w rozumieniu art. $236 \S 2$ kk z 1932 r. Sąd

${ }^{50}$ Rozporządzenie Prezydenta Rzeczypospolitej z dnia 11 lipca 1932 r. - Kodeks karny (Dz. U. Nr 60, poz. 571; dalej: kk z 1932 r.).

51 APR, Sąd Apelacyjny w Radomiu 1939-1945, sygn. 8, k. 276. Wyrok Wyższego Sądu Niemieckiego w Radomiu z 5 maja 1944 r. w sprawie karnej Nps 7/44. 
zasądził także 1000 zł na rzecz pokrzywdzonego tytułem odszkodowania na mocy wniesionego powództwa cywilnego. Od wyroku radomskiego sądu okręgowego J.Z. wniósł apelację do Sądu Apelacyjnego w Radomiu. Sąd Apelacyjny w Radomiu zatwierdził wyrok sądu okręgowego. Oba wyroki sądów polskich (nieniemieckich) nie negowały prawa J.Z. do wystąpienia przeciwko pokrzywdzonemu, zwracały jedynie uwagę, że zachowanie pokrzywdzonego nie dawało podstaw do podejrzenia, że dopuścił się on jakiegokolwiek występku.

Kierownik dystryktowego wydziału sprawiedliwości zwrócił się z wnioskiem o prawo sprawdzenia, uzasadniając, że ,zachowanie się oskarżonego [J.Z. - dopisek H.M.] było może brutalne, należy je jednak, z uwagi na wykonanie przezeń obowiązku służbowego, mającego na celu ochronę obcego majątku i utrzymanie publicznego spokoju, uznać za usprawiedliwione. Skazany nie zauważył, co można zrozumieć i usprawiedliwić, że w dachówce tkwił zardzewiały gwóźdź, który mógł pokaleczyć chłopca. W zachowaniu się skazanego nie można też dopatrzeć się niedbalstwa. Wyrok narusza interes publiczny" ${ }^{52}$.

WSN w Radomiu uchylił wyrok Sądu Okręgowego w Radomiu i uniewinnił J.Z. od stawianych mu zarzutów. Kosztami postępowania została obciążona kasa sądowa GG. Wydatki sądowe za rozpatrzenie powództwa cywilnego miał ponieść pokrzywdzony. Przed WSN w Radomiu przeprowadzono w omawianej sprawie postępowanie dowodowe, przesłuchano ponownie świadków, J.Z. oraz pokrzywdzonego. W uzasadnieniu wyroku sąd przedstawił argumentację, dlaczego nie wzięto pod uwagę zeznań pokrzywdzonego, który zeznał, że oprócz ran nogi został także kilkakrotnie uderzony w plecy. WSN w Radomiu wskazał, że „nie czyni się przez to zarzutu T.R. [pokrzywdzony - dopisek H.M.], jakoby świadomie powiedział nieprawdę. Można wierzyć młodocianemu świadkowi, który bynajmniej nie wywarł na sądzie złego wrażenia, iż starał się przedstawić zajście zgodnie z prawdą. Jednakże nie można wykluczyć u niego fałszywego obrazu pamięciowego. [...] Zachowanie się jego podczas rozprawy głównej, na której jeszcze po tak długim czasie zalał się łzami, wskazuje na istnienie w nim pewnej łatwej pobudliwości”53.

Za główne uchybienie polskich (nieniemieckich) sądów w omawianej sprawie WSN w Radomiu uznał błędną ocenę tego, czy skazany J.Z. działał na mocy przekazanych mu pełnomocnictw służbowych. Zdaniem WSN w Radomiu J.Z. mógł czuć się uprawniony do bezwzględnego występowania przeciwko wszystkim podejrzanym osobom spotkanym na terenie byłej dzielnicy żydowskiej. Działanie na podstawie rozkazu komendanta Schutzpolizei w Ostrowcu wyłączała bezprawność czynu, jakiego dopuścił się J.Z. WSN w Radomiu zauważył jednak, że „chociaż biorąc rzecz obiektywnie, czyn jego z uwagi na udzielone J.R. [ojcu pokrzyw-

\footnotetext{
52 Ibidem, k. 277.

${ }^{53}$ Ibidem, k. 278.
} 
dzonego - dopisek H.M.] policyjne zezwolenie rozbiórki rzeczonego domu, był przeciwny prawu".

W sprawie tej niewątpliwie chodziło o zdjęcie ze skazanego, działającego na podstawie rozkazu komendanta niemieckiej policji, odpowiedzialności karnej za czyn, jakiego dopuścił się w związku z wykonywanymi obowiązkami służbowymi. WSN w Radomiu odrzucił całkowicie zeznania złożone przez pokrzywdzonego, obciążające skazanego J.Z., mimo że w uzasadnieniu stwierdzono, jakoby starał się on mówić prawdę i nie zrobił na sądzie złego wrażenia. W uzasadnieniu w zawoalowany sposób WSN w Radomiu przedstawił argumentację za odrzuceniem najważniejszego dowodu przeciwko J.Z. Drugim faktem świadczącym na niekorzyść J.Z. jest uzyskanie przez ojca pokrzywdzonego od niemieckich władz policyjnych (nie wskazano dokładnie od jakiego organu) zezwolenia na rozbiórkę domu w żydowskiej dzielnicy, a więc także na przebywanie w tej dzielnicy. Zeznania pokrzywdzonego wskazywały, że nie podjął on ucieczki, lecz tłumaczył J.Z. swoją obecność na obszarze byłego getta, który nie słuchając wyjaśnień, pobił pokrzywdzonego dachówką z wbitym gwoździem. Taką albo zbliżoną wersję zdarzeń przyjęły oba sądy polskie (nieniemieckie) rozpatrujące sprawę. Zarówno dystryktowy wydział sprawiedliwości, jak i WSN w Radomiu utrzymywały, że wykonywane z polecenia niemieckiej policji obowiązki służbowe (pilnowanie majątku na obszarze wysiedlonego getta) usprawiedliwiają naruszenie prawa (uszkodzenie ciała), nawet jeżeli to naruszenie wykraczało poza przekazane rozkazy (zgoda na rozbiórkę domu i przebywanie na obszarze wysiedlonego getta dla ojca pokrzywdzonego). Sądy polskie (nieniemieckie) nie mogły skazywać za działania podejmowane z rozkazu niemieckich władz.

W trzeciej ze spraw karnych, która była rozpatrywana przez WSN w Radomiu w ramach procedury prawa sprawdzenia, J.K. została skazana za czynną napaść na urzędnika ${ }^{54}$. Zastępca sołtysa z Młynar w dniu 1 marca 1943 r. udał się do W.K., aby wezwać go do stawienia furmanek w dniu następnym do przewozu wag do urzędu miar w Piotrkowie. Skazana J.K., będąca żoną W.K., gdy usłyszała o obowiązku stawienia furmanek, zaczęła wyzywać zastępcę sołtysa, po czym dwukrotnie uderzyła go w twarz. Po tym, jak zastępca sołtysa chciał ją odepchnąć, zaczęła bić go szczotką po głowie. J.K. została skazana przez Sąd Grodzki w Piotrkowie na podstawie art. 132 § 1 i 133 § 1 kk z 1932 r. za zniewagę urzędnika i czynną napaść na urzędnika na łączną karę 6 miesięcy więzienia. Na skutek apelacji wniesionej przez J.K. Sąd Okręgowy w Piotrkowie uchylił wyrok sądu I instancji, argumentując, że na podstawie art. $132 \S 1 \mathrm{kk} \mathrm{z} 1932$ r. można było orzec tylko karę aresztu, a nie więzienia oraz że powinno nastąpić skazanie nie za czynną napaść uregulowaną

${ }^{54}$ APR, Sąd Apelacyjny w Radomiu 1939-1945, sygn. 8, k. 319-321. Wyrok Wyższego Sądu Niemieckiego w Radomiu z 5 maja 1944 r. w sprawie karnej Nps 9/44. 
w art. 133 § 1 kk z 1932 r., ale za zmuszenie urzędnika z art. 129 kk z 1932 r. Sąd Okręgowy w Piotrkowie skazał J.K. na podstawie art. 133 § 1 i art. 129 kk z 1932 r. na łączną karę jednego miesiąca aresztu.

Do WSN w Radomiu wniosek o sprawdzenie prawomocnego wyroku złożył kierownik dystryktowego wydziału sprawiedliwości w Radomiu, uzasadniając go naruszeniem interesu publicznego poprzez przyjęcie błędnej kwalifikacji prawnej oraz zbyt niską karę, jaka została orzeczona. Zdaniem dystryktowego wydziału sprawiedliwości J.K. powinna była zostać skazana za czynną napaść na urzędnika (art. 133 kk z 1932 r.), a nie za przestępstwo zmuszenia urzędnika (art. 129 kk z 1932 r.). Kara jednego miesiąca aresztu została uznana za niewystarczającą odpłatę za zachowanie J.K.

Zdaniem WSN w Radomiu J.K., uderzając zastępcę sołtysa, nie chciała wymusić na nim cofnięcia zarządzenia o stawieniu furmanek, a jedynie wyładować swą złość. Miała to być więc czynna napaść na urzędnika podczas pełnienia przez niego obowiązków służbowych. WSN w Radomiu powołał się także na zeznania świadka sołtysa, który zeznał, że J.K. opiera się wszystkim zarządzeniom władz i często wyzywa „organy wykonawcze”.

Karę orzeczoną przez Sąd Okręgowy w Piotrkowie WSN w Radomiu uznał za niewystarczającą odpłatę za czyn skazanej. Jak wskazano w uzasadnieniu do wyroku: „Pracujący w interesie niemieckim polscy sołtysi muszą być przy pełnieniu ich ciężkiej i odpowiedzialnej służby jak najdalej chronieni przed napaścią niesfornych mieszkańców wsi. W takich przypadkach muszą więc być orzekane znacznie dotkliwsze kary pozbawienia wolności" ${ }^{55}$. WSN w Radomiu negatywnie ocenił także przyjętą przez sądy polskie (nieniemieckie) kwalifikację prawną zachowania skazanej J.K. jako dwóch odrębnych czynów: znieważenia urzędnika i czynnej napaści na urzędnika (zmuszenia urzędnika). Zdaniem sądu niemieckiego zamiar skazanej od początku ukierunkowany był na wyzwanie i uderzenie urzędnika. Błędna kwalifikacja prawna czynu była podstawą dla WSN w Radomiu do zniesienia wyroków sądu grodzkiego i sądu okręgowego oraz przekazania sprawy do rozpatrzenia Sądowi Specjalnemu w Radomiu.

W wyżej scharakteryzowanej sprawie WSN w Radomiu wprost uzasadnił motywy stojące za wzruszeniem prawomocnych wyroków sądów polskich (nieniemieckich). Władzom niemieckim chodziło bowiem o surowe karanie przez sądy polskie (nieniemieckie) za wszelkie wystąpienia przeciwko urzędnikom narodowości polskiej pracującym „w interesie niemieckim”, a więc jednocześnie zapewnienie im ochrony. Dlatego w omawianej sprawie, w której skazana wystąpiła przeciwko zastępcy sołtysa, za wadliwe uznano przyjęcie łagodniejszej kwalifikacji prawnej i orzeczenie zbyt niskiej kary.

${ }^{55}$ Ibidem, k. 320. 


\section{SPRAWY CYWILNE}

Wśród spraw cywilnych, które były rozpatrywane w ramach procedury prawa sprawdzenia przez WSN w Radomiu, dominują dwa ich rodzaje, związane z prowadzoną przez okupantów niemieckich polityką gospodarczej eksploatacji. Pierwszy rodzaj to sprawy, które dotyczyły orzekania, w różnych rodzajach postępowań, przez sądy polskie (nieniemieckie) o podziałach nieruchomości rolnych. Drugi to sprawy dotyczące postępowań, w których sądy orzekły o świadczeniach w naturze - chodziło o produkty, których obrót był zakazany przez prawo GG. Pozostałe rozpatrywane sprawy odbiegały od tych dwóch rodzajów i były przedmiotem zainteresowania władz niemieckich z przyczyn bardziej prawnych niż politycznych.

$\mathrm{Na}$ trzydzieści dwie sprawy cywilne, rozpatrywane przez WSN w Radomiu w ramach procedury prawa sprawdzenia dwadzieścia dotyczyło rozdrabniania przez sądy polskie (nieniemieckie) nieruchomości rolnych, z czego siedemnaście z nich było związanych z działami spadków ${ }^{56}$, dwie $\mathrm{z}$ odwołaniem darowizny ${ }^{57}$ a jedna dotyczyła zakłóconego posiadania ${ }^{58}$.

We wszystkich tych sprawach, które kończyły się rozdrobnieniem nieruchomości rolnych, dystryktowy wydział sprawiedliwości mniej więcej w ten sam sposób wskazywał na naruszenie interesu publicznego. Podnoszono, że ogólny interes publiczny wymaga utrzymania zdolnych do życia gospodarstw i zakazuje rozdrabniania ich na niezdolne do życia części. Tylko zdolne do życia przedsiębiorstwa rolne mogły być obciążane wymaganymi kontyngentami. „Interes gospodarczy ogółu" wymagał więc utrzymania większych i zdolnych do produkcji gospodarstw rolnych, które mogły być obciążane wymaganymi zobowiązaniami dostarczenia kontyngentów i miały być w stanie zabezpieczyć wyżywienie ogółu ludności GG ${ }^{59}$. W jednym przypadku problemem było nie tyle rozdrobnienie nieruchomości gruntowej, ponieważ w świetle oceny władz niemieckich to gospodarstwo rolne było „zaledwie zdolne do życia”, ile ryzko niewypełnienia zobowiązań kontyngentowych, ponieważ będący w podeszłym wieku powód nie dawał gwarancji, że będzie mógł prowadzić intensywną gospodarkę na małym, zaledwie zdolnym do życia gospodarstwie. Tego typu twierdzenia pojawiały się we wnioskach o sprawdzenie prawomocnych orzeczeń sądów polskich (nieniemieckich).

Inicjatorami wniosków o sprawdzenie prawomocnych orzeczeń sądów polskich (nieniemieckich), które rozdrabniały nieruchomości rolne, w większości

${ }^{56}$ Były to sprawy o sygn.: Np 5/42, Np 6/42, Np 7/42, Np 8/42, Np 1/43, Np 3/43, Np 8/43, Np 9/43, Np 10/43, Np 11/43, Np 14/43, Np 15/43, Np 18/43, Np 21/43, Np 22/43, Np 23/43, Np 1/44.

${ }^{57}$ Były to sprawy o sygn. Np 9/42, Np 6/43.

${ }^{58}$ Była to sprawa o sygn. Np 2/43.

59 APR, Sąd Apelacyjny w Radomiu 1939-1945, sygn. 8, k. 66-67. Wyrok Wyższego Sądu Niemieckiego w Radomiu z 20 października 1943 r. w sprawie cywilnej Np 9/43. 
przypadków byli starostowie (Stadt-Kreishauptmann) lub agronomowie powiatowi (Kreislandwirt). Można przyjąć taką tezę, ponieważ do wniosków radomskiego wydziału sprawiedliwości dołączane były pisma tych organów, informujące o podziale nieruchomości zmniejszającym kontyngenty. Na ocenę agronomów powiatowych co do wielkości gospodarstw oraz ich możliwości produkcyjnych powoływał się także w swoich uzasadnieniach WSN w Radomiu ${ }^{60}$.

We wszystkich dwudziestu sprawach dotyczących orzeczeń o rozdrobnienie nieruchomości WSN w Radomiu orzekł zgodnie z wnioskiem dystryktowego wydziału sprawiedliwości, tzn. uchylił wyrok sądu polskiego i albo sam merytorycznie orzekł, albo - tak jak w sześciu przypadkach - przekazał sprawę do rozpatrzenia sądowi niemieckiemu. W tych sprawach, w których znajdowała się informacja, że dana osoba jest dobrym gospodarzem, WSN w Radomiu sam merytorycznie zmieniał wyrok sądu polskiego (nieniemieckiego). WSN w Radomiu przyznawał całą nieruchomość jednemu ze spadkobierców z jednoczesnym zobowiązaniem do spłaty pozostałych spadkobierców w gotówce ${ }^{61}$.

Podstawą prawną przeprowadzania działów nieruchomości spadkowych przez sądy polskie (nieniemieckie) w dystrykcie radomskim był art. 826 Kodeksu Napoleona, w świetle którego każdy ze współspadkobierców mógł żądać swego udziału w naturze z ruchomości i nieruchomości. WSN w Radomiu, oceniając pod kątem prawnym wyroki sądów polskich (nieniemieckich) we wszystkich tych sprawach, uzasadniał mniej więcej w taki sam sposób: „W myśl art. $826 \mathrm{KC}$ jest każdy współspadkobierca w zasadzie uprawniony do żądania swego udziału spadku w naturze. Art. 22 przepisów wprowadzających daje jednak sądowi możność przy podziałach gospodarstw rolnych rozstrzygnięcia w ten sposób, że tylko jednemu spadkobiercy przysądza się posiadłość w naturze, podczas gdy pozostali współspadkobiercy otrzymują spłaty pieniężne" ${ }^{2}$. WSN w Radomiu odnosił się więc do utrzymanego w mocy art. 22 przepisów przechodnich z 19 sierpnia 1917 r. do ustawy postępowania cywilnego ${ }^{63}$, zgodnie z którym sądy miały możliwość przy podziałach małej własności rolnej poza miastami podzielenia tych nieruchomości poprzez przyznanie całej nieruchomości spadkowej jednemu spadkobiercy na wyłączną własność, przy jednoczesnym przyznaniu pozostałym spadkobiercom spłat pieniężnych.

${ }^{60} \mathrm{Na}$ takie pisma powołano się m.in. w sprawach o sygn. Np 7/42, Np 18/43.

${ }^{61}$ APR, Sąd Apelacyjny w Radomiu 1939-1945, sygn. 8, k. 47-48. Wyrok Wyższego Sądu Niemieckiego w Radomiu z 31 marca 1943 r. w sprawie cywilnej Np 8/42.

${ }^{62}$ Ibidem, k. 52.

${ }^{63}$ Przepisy przechodnie do ustawy postępowania cywilnego z 19 sierpnia 1917 r. (Dziennik Urzędowy Departamentu Sprawiedliwości Tymczasowej Rady Stanu Królestwa Polskiego 1917, nr 1). Przepis utrzymany w mocy na podstawie art. XVII $\S 2$ pkt 2 rozporządzenia Prezydenta Rzeczypospolitej z 29 listopada 1930 r. - Przepisy wprowadzające Kodeks Postępowania Cywilnego, (Dz.U. Nr 83, poz. 652). 
Nieco odmienny charakter, ale wpisujący się w kwestie wielkości i produktywności gospodarstw rolnych, miała jedna ze spraw o odwołanie darowizny. Sąd Okręgowy w Radomiu w postępowaniu apelacyjnym zwrócił powodowi (darczyńcy) przekazaną w darowiźnie w listopadzie 1939 r. nieruchomość rolną z powodu rażącej niewdzięczności, określonej w art. $366 \mathrm{kz}^{64}$. Zdaniem dystryktowego wydziału sprawiedliwości umowa miała faktycznie charakter umowy dożywocia, a nie umowy darowizny, dlatego nie można było do niej zastosować przepisów o odwołaniu darowizny z powodu rażącej niewdzięczności. Naruszeniem interesu publicznego - zdaniem dystryktowego wydziału sprawiedliwości - było przyznanie nieruchomości powodowi, którego podeszły wiek nie dawał gwarancji, że będzie on mógł prowadzić intensywną gospodarkę, co zagrażało wypełnianiu zobowiązań kontyngentowych. Wskazano, że „Stałość stosunków własnościowych gruntów rolnych jest, zwłaszcza podczas wojny, ważnym warunkiem odbywającej się bez przeszkód produkcji”" ${ }^{65}$. WSN w Radomiu przychylił się do oceny, że umowa miała charakter umowy dożywocia, a nie umowy darowizny. Przy czym usprawiedliwił pozwanych, że niewypełnianie przez nich zobowiązań wynikających z umowy w tej sprawie było spowodowane ciążącymi na nich obowiązkami i przepisami o gospodarce kierowanej, a więc dostarczania kontyngentów.

W ośmiu sprawach cywilnych wszczęta została procedura prawna sprawdzenia, ponieważ pojawiła się w nich kwestia zasądzenia przez sądy świadczenia naturalnego zakazanymi (w większości przypadków chodziło o zasądzenie czynszu) przez prawo GG produktami - głównie dotyczyło to zboża. Wszystkie te sprawy miały podobny charakter, dystryktowy wydział sprawiedliwości powoływał się na naruszenie interesu publicznego poprzez to, że wyroki były sprzeczne z prawem GG. W myśl zarządzenia o gospodarce zbożem i paszą w roku gospodarczym 1941/1942 z dnia 17 lipca 1941 r. ${ }^{66}$ zakłady wytwórcze były zobowiązane dostarczyć do dopuszczonych przez dystryktowe wydziały wyżywienia i rolnictwa zakładów i osób całe zboże, które nie było potrzebne do wyżywienia ludzi, jako deputat do celów zasiewu lub jako pasza do należących do zakładu wytwórczego zwierząt ${ }^{67}$. WSN w Radomiu w sprawach o świadczenie zboża przyjmował argumentację dystryktowego wydziału sprawiedliwości, stwierdzał naruszenie prawa GG i zazwyczaj uchylał wyroki sądów w części dotyczącej zakazanego świadczenia.

${ }^{64}$ Rozporządzenie Prezydenta Rzeczypospolitej z dnia 27 października 1933 r. - Kodeks zobowiązań (Dz.U. Nr 82, poz. 598; dalej: kz).

${ }^{65}$ APR, Sąd Apelacyjny w Radomiu 1939-1945, sygn. 8, k. 284. Wyrok Wyższego Sądu Niemieckiego w Radomiu z 24 lutego 1943 r. w sprawie cywilnej Np 6/43.

${ }^{66}$ Zarządzenie o gospodarce zbożem i paszą w roku gospodarczym 1941/1942 z 17 lipca 1941 r. (Dziennik Rozporządzeń dla Generalnego Gubernatorstwa [dalej: Dz. RGG], nr 64, s. 419). Analogiczne zarządzenia były wydawane także w późniejszych latach.

${ }^{67}$ Ibidem, $§ 2$. 
Polecenie wszczynania postępowań o sprawdzenie prawomocnych orzeczeń sądów polskich (nieniemieckich), w których doszło do zasądzenia świadczeń w zbożu, kierownik Wydziału Sprawiedliwości w Urzędzie Gubernatora Dystryktu Radomskiego otrzymał 7 grudnia 1940 r. od kierownika Głównego Wydziału Sprawiedliwości w Rządzie GG Kurta Willego ${ }^{68}$. W piśmie tym wyraźnie wskazano, że wyroki takie były sprzeczne z prawem GG i nie mogły być egzekwowane. Kierownik dystryktowego wydziału sprawiedliwości miał pouczyć sądy o rozpatrywaniu tego typu spraw zgodnie z prawem GG.

Powyższe dwie kategorie spraw dotyczące rozdrabniania nieruchomości rolnych i świadczeń w dobrach zakazanych były wzruszane przez władze niemieckie z uwagi na sprzeczność orzeczeń sądów polskich (nieniemieckich) z polityką prowadzoną przez okupantów niemieckich na obszarze GG - eksploatacją ekonomiczną ludności ${ }^{69}$. Orzeczenia te mogły bowiem pośrednio lub bezpośrednio prowadzić do zmniejszenia obciążeń kontyngentowych czy obowiązku dostarczania zbóż. O związaniu WSN w Radomiu celami prowadzonej polityki ekonomicznej świadczy zapytanie złożone w jednej ze spraw do Wydziału Wyżywienia i Rolnictwa w Urzędzie Gubernatora Dystryktu Radomskiego o to, czy dopuszczalne byłoby przyznanie gospodarki rolnej kilku spadkobiercom jako współwłaścicielom i czy takie rozwiązanie nie naruszałoby ogólnego interesu ${ }^{70}$. Chodziło więc o potwierdzenie, czy takie rozwiązanie nie zmniejszyłoby wysokości świadczonych kontyngentów. Powyższa sytuacja, będąca de facto pytaniem sądu o zgodę na wydanie konkretnego wyroku, pokazuje brak realnej niezależności w orzekaniu Wyższego Sądu Niemieckiego w Radomiu.

Bardziej interesująca wydaje się postawa sądów polskich (nieniemieckich), które pomimo jednolitego orzecznictwa WSN w Radomiu, zabraniającego działów nieruchomości rolnych, nadal wydawały takie orzeczenia. Praktyka taka wynikać mogła z jednej strony z faktu orzekania zgodnie z żądaniami pozwów o dokonanie działów, mieszczących się w granicach obowiązującego prawa i niewątpliwie wypełniających podstawową potrzebę gospodarki rolnej - posiadanie ziemi. Z drugiej

${ }^{68}$ APR, Niemiecki Sąd Wyższy w Radomiu, sygn. 4, k. 2. Pismo kierownika Głównego Wydziału Sprawiedliwości Kurta Willego z 7 grudnia 1940 r. w sprawie wyroków zasądzających świadczenie w zbożu.

${ }^{69}$ Więcej na ten temat: D. Brewing, W cieniu Auschwitz. Niemieckie masakry polskiej ludności cywilnej 1939-1945, Poznań 2019, s. 133 i n. Zwiększenie eksportu kontyngentów żywnościowych do „starej Rzeszy” było jednym z sukcesów niemieckiej administracji agrarnej. Przez cały okres okupacji z Generalnego Gubernatorstwa do Rzeszy dostarczono ponad 1,3 mln ton zboża, $1 \mathrm{mln}$ ton ziemniaków, 140 tys. ton bydła, $500 \mathrm{mln}$ jajek, 10 tys. ton thuszczów oraz kilkaset tysięcy ton kur i koni. Dane za: Cz. Łuczak, Polityka ekonomiczna i ludnościowa hitlerowskich Niemiec w okupowanej Polsce, Poznań 1993, s. 402.

${ }^{70}$ APR, Sąd Apelacyjny w Radomiu 1939-1945, sygn. 8, k. 192-193. Wyrok Wyższego Sądu Niemieckiego w Radomiu z 16 lutego 1944 r. w sprawie cywilnej Np 21/43. 
strony ocena, czy dane gospodarstwo było na tyle duże, by mogło być podzielone, była czysto arbitralna i najprawdopodobniej podejmowana przez niemieckie władze na poziomie powiatu. Organy te inicjowały także procedurę sprawdzenia prawomocnych orzeczeń sądów polskich (nieniemieckich). Sądy polskie (nieniemieckie) miały świadomość możliwości wzruszenia ich wyroków działowych, dlatego uzasadniano podjętą decyzję, np. wskazując, że w tej samej miejscowości funkcjonuje kilka gospodarstw tej samej wielkości ${ }^{71}$. W Sądzie Apelacyjnym w Radomiu, gromadzącym odpisy orzeczeń wydanych przez WSN w Radomiu i informującym o ich treści wszystkie polskie (nieniemieckie) sądy w dystrykcie radomskim, starano się znaleźć w orzecznictwie WSN w Radomiu jakąś normę wielkościową, powyżej której możliwe byłoby orzeczenie działu nieruchomości. Na gromadzonych odpisach zaznaczano np. ,7ha = 15 morgów są niepodzielne"72.

Trudniej jest wytłumaczyć dalsze orzekanie przez sądy polskie (nieniemieckie) świadczeń w naturze. Orzeczenia tego typu były sprawdzane przez WSN w Radomiu w różnych latach okupacji. Niemożliwe jest, że zakaz orzekania tego typu świadczeń, sprzecznych z prawem GG, nie dotarł do sądów niższej instancji, na pewno były one informowane poprzez przesyłanie odpisów wyroków WSN w Radomiu oraz w instrukcjach od sądów wyższych instancji. W ostatniej sprawie dotyczącej zasądzenia świadczenia towarów wyłączonych z obrotu, rozpatrzonej przez WSN w Radomiu 24 maja 1944 r., zarówno sąd grodzki, jak i sąd okręgowy miały świadomość, że nie można zgodnie z żądaniem pozwu zasądzić zboża i ziemniaków. Sąd grodzki zasądził w tej sprawie świadczenie torfu i drzewa. Sąd okręgowy zaproponował stronie powodowej, ze względu na obowiązujące przepisy, czy nie chciałaby zmienić żądania na świadczenie pieniężne. Brak odpowiedzi strony powodowej spowodował, że sąd okręgowy w tej sprawie orzekł świadczenie w postaci 6 sążni torfu, jednocześnie oddalił pozew dotyczący $9 \mathrm{~m}^{3}$ drewna, ze względu na wyłączenie drewna $z$ wolnego handlu ${ }^{73}$. Prawomocny wyrok w niniejszej sprawie został wzruszony, ponieważ prawo GG zakazywało także obrotu torfem ${ }^{74}$. Powyższa sprawa pokazuje, że sądy polskie (nieniemieckie) miały świadomość istnienia zakazu obrotu niektórymi towarami w prawie GG, a więc także zasądzania świadczeń w naturze. Co więcej, sądy starały się orzekać zgodnie z prawem GG. Problemem w całym GG była jednak dostępność oficjal-

${ }^{71}$ APR, Sąd Apelacyjny w Radomiu 1939-1945, sygn. 8, k. 109. Wyrok Wyższego Sądu Niemieckiego w Radomiu z 24 listopada 1943 r. w sprawie cywilnej Np 18/43.

72 APR, Sąd Apelacyjny w Radomiu 1939-1945, sygn. 8, k. 365. Wyrok Wyższego Sądu Niemieckiego w Radomiu z 27 lutego1943 r. w sprawie cywilnej Np 6/43.

${ }^{73}$ APR, Sąd Apelacyjny w Radomiu 1939-1945, sygn. 8, k. 315. Wyrok Wyższego Sądu Niemieckiego w Radomiu z 24 maja 1944 r. w sprawie cywilnej Np 10/44.

${ }^{74}$ Rozporządzenie o ekspolatacji torfu w Generalnym Gubernatorstwie z 22 kwietnia $1941 \mathrm{r}$. (Dz. RGG, nr 37, s. 235). W myśl § 1 o dostarczeniu, rozdzieleniu, zbyciu i użyciu torfu jako materiału opałowego decydował urząd gospodarowania węglem w Generalnym Gubernatorstwie. 
nych publikatorów, która pozwalałaby na zaznajomienie się z tym prawem. Sądy polskie (nieniemieckie) wielokrotnie zwracały się do sądów wyższej instancji oraz nadzorczych organów administracyjnych o dostarczenie im najnowszych przepisów. Problemy te najprawdopodobniej powodowały wzruszanie tego typu orzeczeń.

Jak już wspomniano, w pozostałych sprawach cywilnych, które były rozpatrywane przez WSN w Radomiu w ramach procedury prawa sprawdzenia, większe znaczenie miały kwestie jurydyczne wydanych orzeczeń niż problematyka polityczno-ekonomiczna.

W pierwszej sprawie cywilnej tego typu, na tle sporu o zapłatę emerytury oraz odszkodowania za wypowiedzenie umowy o pracę, w której pozwaną była gmina Wyśmierzyce, powstał problem statusu prawnego gmin $\mathrm{GG}^{75}$. W sprawie tej wyrok w I instancji Sądu Okręgowego w Radomiu zapadł 22 kwietnia 1939 r., a więc jeszcze przed wybuchem II wojny światowej, natomiast wyrok Sądu Apelacyjnego w Radomiu został wydany 25 lipca 1940 r. Powodem wszczęcia procedury prawa sprawdzenia, ujawnionym w uzasadnieniu do wniosku o sprawdzenie prawomocnego orzeczenia skierowanego do WSN w Radomiu przez dystryktowy wydział sprawiedliwości w Radomiu, była kwestia, że wyrok sądu I instancji dotyczył gminy miejskiej państwa polskiego, natomiast wyrok sądu II instancji - gminy miejskiej GG. Sąd Apelacyjny w Radomiu nie zajął żadnego stanowiska w kwestii tego, czy gmina miejska GG była tym samym podmiotem prawa, co gmina miejska państwa polskiego, a więc czy zachodziło następstwo prawne między tymi podmiotami.

WSN w Radomiu, pomimo jurydycznego problemu, jaki pojawił się w tej sprawie, przyjął argumentację nacechowaną ideologicznie. Po pierwsze, podniesiono, że zbadanie statusu prawnego pozwanej (gminy) w tej sprawie było wskazane, ponieważ państwo polskie ,załamało się zupełnie pod wpływem zwycięstwa broni niemieckiej" ${ }^{\prime \prime}$. WSN w Radomiu uznał więc kontrowersyjną, nawet dla nazistowskich prawników, tezę o debellatio państwa polskiego ${ }^{77}$. Zdaniem wyższego sądu niemieckiego nie można było więc wykluczyć zmiany statusu prawnego gmin miejskich w GG.

Według WSN w Radomiu nie można było jednak uznać, że gminy byłego państwa polskiego przestały istnieć, a gminy GG miałyby być uznawane za nowo powstałe osoby prawne prawa publicznego. Argumentami za taką tezą miał być fakt, że ustawodawca GG uregulował (wyrok w omawianej sprawie wydano

75 APR, Sąd Apelacyjny w Radomiu 1939-1945, sygn. 8, k. 255. Wyrok Wyższego Sądu Niemieckiego w Radomiu z 2 lutego 1942 r. w sprawie cywilnej Np 1/40.

${ }^{76}$ Ibidem, k. 260.

77 Tezę o zawojowaniu państwa polskiego przedstawili dr A. Weh i dr F. Klein. Miała ona jednak charakter lokalny, znajdujący zwolenników wyłącznie w samym GG. Najwyższe władze III Rzeszy i przedstawiciele niemieckiej nauki prawa międzynarodowego nie uznawali tej teorii. Więcej na ten temat: A. Klafkowski, Okupacja niemiecka w Polsce w świetle prawa narodów, Poznań 1946, s. 103-104. 
5 lutego 1942 r.) wiele dziedzin życia publicznego i prywatnego w Generalnym Gubernatorstwie, gdyby więc chciał odmiennie uregulować status prawny gmin miejskich, wprowadziłby w tej dziedzinie właściwe przepisy. Władze GG wydały wiele przepisów dotyczących osób prawnych prawa publicznego, np. związków komunalnych, przy czym zgodnie z opinią WSN w Radomiu przepisy te miały dotyczyć nowo utworzonych podmiotów, nie zachodziło więc następstwo prawne (np. między związkami komunalnymi a polskimi związkami powiatowymi).

WSN w Radomiu w taki sposób tłumaczył następstwo prawne pomiędzy gminami miejskimi państwa polskiego a gminami miejskimi GG: „Gminy miejskie Generalnego Gubernatorstwa nie są jednakże żadnymi nowymi tworami. Istnieją one częściowo już od stuleci i są, jak to stwierdzono, założone przez Niemców w myśl prawa magdeburskiego lub innego prawa miejskiego. Przetrwały one różne zmiany kierownictwa państwa, przy czym nie zmieniła się ich struktura prawna, jako korporacji prawa publicznego [...] życie w samorządzie komunalnym ma się rozwijać tak jak dotychczas pod nadzorem niemieckim"78. Osobowość prawna gmin miejskich pomimo zmiany „kierownictwa państwa” miała pozostać bez zmian i gminy GG były następcami prawnymi gmin państwa polskiego.

Powyższa sprawa była rozpatrywana przez WSN w Radomiu przez prawie dwa lata (wniosek do WSN w Radomiu wpłynął 19 lutego 1940 r.). Wynika to najprawdopodobniej z faktu ustalenia statusu prawnego (przynależności „,narodowościowej”) gmin w GG dopiero pod koniec 1941 r. W grudniu 1941 r. wydany został reskrypt Głównego Wydziału Sprawiedliwości w Rządzie GG, w którym stwierdzono, że sprawy sądowe korporacji publiczno-prawnych, związków gmin, fundacji i zakładów utworzonych w GG na podstawie prawa niemieckiego powinny były być rozpatrywane przez sądy niemieckie. Gminy GG, określone w reskrypcie jako ,polskie”, uznane zostały za osoby prawne polskiego prawa publicznego, podlegające właściwości sądów polskich (nieniemieckich) w GG. Burmistrzowie gmin uznani zostali za wyłącznych prawnych przedstawicieli gmin i bez znaczenia był fakt ich podlegania nadzorowi władz niemieckich ${ }^{79}$. Powyższe regulacje znajdują odzwierciedlenie w wyroku WSN w Radomiu, uznającym następstwo prawne pomiędzy gminami państwa polskiego a gminami GG.

Inny problem prawny, będący przyczyną wszczęcia procedury prawa sprawdzenia, powstał na tle sprawy o przywrócenie zakłóconego posiadania ${ }^{80}$. Problem

${ }^{78}$ APR, Sąd Apelacyjny w Radomiu 1939-1945, sygn. 8, k. 261. Wyrok Wyższego Sądu Niemieckiego w Radomiu z 2 lutego 1942 r. w sprawie cywilnej Np 1/40.

79 Archiwum Państwowe w Lublinie Oddział w Radzyniu Podlaskim, Sąd Grodzki w Parczewie, sygn. 5, k. 5. Pismo kierownika Wydziału Sprawiedliwości w Urzędzie Gubernatora Dystryktu Lubelskiego z 12 grudnia $1941 \mathrm{r}$. w sprawie właściwości sądów w procesach polskich gmin.

${ }^{80}$ APR, Sąd Apelacyjny w Radomiu 1939-1945, sygn. 8, k. 82. Wyrok Wyższego Sądu Niemieckiego w Radomiu z 23 czerwca 1943 r. w sprawie cywilnej Np 4/43. 
prawny, jaki rozstrzygnął WSN, dotyczył kwestii uzyskania pozwolenia na zbycie nieruchomości na podstawie rozporządzenia z 17 marca 1940 r. o obrocie nieruchomościami w Generalnym Gubernatorstwie. Zdaniem WSN w Radomiu zezwolenie starosty powiatowego na zbycie nieruchomości musiało być wyrażone w jasny sposób, nie mogło mieć milczącego charakteru (w niniejszej sprawie strona uznała, że zgoda została udzielona, ponieważ starosta kazał odpowiednio opłacić wniosek). W sprawie tej dodatkowo naruszeniem interesu publicznego było to, że zgoda miała być udzielona na zbycie nieruchomości żydowskich właścicieli. Brak udzielenia zgody na zbycie nieruchomości spowodował, że majątek powinien stać się własnością Generalnego Gubernatorstwa.

W kolejnej sprawie rozpatrywanej przez WSN w Radomiu w ramach procedury prawa sprawdzenia ocenie poddane zostało postanowienie sądu okręgowego, w którym stwierdzono, że właściwym do dokonania wpisu do rejestru handlowego jest sąd niemiecki ${ }^{81}$. W świetle prawa GG sąd polski (nieniemiecki) nie miał kompetencji do badania swojej właściwości. Zgodnie z $§ 6$ rozporządzenia o przejściu spraw w niemieckim i polskim sądownictwie z 19 lutego 1940 r. sąd polski (nieniemiecki) w razie istnienia sporu lub wątpliwości co do tego, czy sprawa podlega sądownictwu polskiemu, czy niemieckiemu, powinien przekazać sprawę do rozstrzygnięcia właściwemu sądowi niemieckiemu albo wyższemu sądowi niemieckiemu. W omawianej sprawie polski (nieniemiecki) sąd sam rozstrzygnął o swojej niewłaściwości i przekazał sprawę do merytorycznego załatwienia właściwemu sądowi niemieckiemu, a nie w celu rozstrzygnięcia sporu o właściwość. WSN w Radomiu uznał, że sąd polski (nieniemiecki), chociaż byłby przekonany, że sprawa podlega niemieckiemu sądownictwu, nie może sam o tym decydować, lecz powinien przekazać sprawę do rozstrzygnięcia właściwemu sądowi niemieckiemu. W sprawie tej WSN w Radomiu rozstrzygnął też, że dla kwestii właściwości dokonania wpisu do rejestru handlowego bez znaczenia było niemieckie obywatelstwo zarządcy nieprzyjacielskiego majątku.

Niewątpliwie najważniejsze znaczenie prawne dla praktyki sądowej miał wyrok wydany przez WSN w Radomiu w sprawie Np 5/43 ${ }^{82}$. W tym przypadku wierzyciel (późniejszy pozwany) „Bank Spółdzielczy z ograniczoną odpowiedzialnością w Kielcach" uzyskał prawomocne sądowe tytuły egzekucyjne w 1933 i 1935 r. w sprawach o zapłatę długów z weksli protestowanych. Na podstawie tych tytułów, zaopatrzonych w klauzulę wykonalności, wierzyciel usiłował w 1942 r. dochodzić swego roszczenia przez zajęcie. Dłużnicy wystąpili do sądu grodzkiego z pozwem o rozłożenie długu w wysokości 1200 zł na raty. Sąd okręgowy, zmieniając wyro-

${ }^{81}$ APR, Sąd Apelacyjny w Radomiu 1939-1945, sygn. 8, k. 303. Wyrok Wyższego Sądu Niemieckiego w Radomiu z 12 maja 1944 r. w sprawie cywilnej Np 11/44.

${ }^{82}$ APR, Sąd Apelacyjny w Radomiu 1939-1945, sygn. 8, k. 70. Wyrok Wyższego Sądu Niemieckiego w Radomiu z 23 czerwca 1943 r. w sprawie cywilnej Np 5/43. 
kiem z 20 listopada 1942 r. wyrok sądu grodzkiego oddalający powództwo, rozłożył należność na dwie raty, a więc zmienił sposób wykonania świadczenia ustalonego prawomocnym orzeczeniem sądu. Sąd okręgowy zaznaczył w motywach, że w danych warunkach nie było przesłanek do zastosowania art. $269 \mathrm{kz}$. Sąd powołał się na to, że w pewnych indywidualnych wypadkach względy słuszności mogły prowadzić do wniosku, że nawet obowiązek płacenia, orzeczony prawomocnym wyrokiem sądowym, mógł być zmieniony co do sposobu wykonania. Mogło to się odnieść w szczególności do rozłożenia na raty sumy prawomocnie zasądzonej. Trudności gospodarcze, wywołane długotrwałością zdarzeń wojennych, w jakich powodowie znaleźli się bez swej winy, były tego rodzaju, że nawet obowiązek orzeczony prawomocnym wyrokiem jednorazowej zapłaty powinien zostać złagodzony. Na tle niniejszej sprawy pojawiły się dwa problemy prawne: czy możliwa była zmiana prawomocnego orzeczenia sądowego w ramach klauzuli rebus sic stantibus (art. $269 \mathrm{kz}$ )? Czy możliwa była sądowa zmiana sposobu świadczenia ustalonego prawomocnym orzeczeniem sądowym z uwagi na względy słuszności?

Kierownik Wydziału Sprawiedliwości w Urzędzie Gubernatora Dystryktu Radomskiego wniósł do WSN w Radomiu wniosek o sprawdzenie prawomocnego wyroku sądu okręgowego. Jako naruszenie interesu publicznego wskazano, że dokonana zmiana prawomocnego wyroku bez ustawowej podstawy wywołała niepewność w obrocie prawnym i zagrażała gospodarce kredytowej spółdzielni, obejmującej szerokie kręgi, co stawiało ją pod znakiem zapytania ${ }^{83}$.

O wyjątkowości omawianej sprawy świadczy nie tylko doniosłe zagadnienie prawne, jakie pojawiło się na jej tle, ale także fakt, że strona pozwana w postępowaniu przed WSN w Radomiu przedłożyła wyższemu sądowi niemieckiemu tezę prawną uchwaloną przez Sąd Apelacyjny w Radomiu. W żadnej z pozostałych analizowanych spraw taka sytuacja nie miała miejsca.

WSN w Radomiu przedłożona została teza nr 17 Sądu Apelacyjnego w Radomiu, uchwalona 23 marca 1943 r., przy czym wnioskodawcą sporządzenia tezy prawnej do przedstawionych zagadnień prawnych był Witold Prądzyński, kierownik Sądu Apelacyjnego w Radomiu ${ }^{84}$. Przedstawione zostały trzy zagadnienia prawne powstałe na tle tej samej sprawy, która była przedmiotem omawianego postępowania przed WSN w Radomiu. Sąd Apelacyjny w Radomiu uchwalił, że:

1. Sąd nie może stosować art. $269 \mathrm{kz}$ odnośnie do świadczeń ustalonych prawomocnymi tytułami egzekucji sądowej, wymienionymi w art. 527 pkt 1 i 3 kpc, o ile są nimi wyroki sądów państwowych, nakazy zapłaty i wyroki sądów polubownych, i to bez względu na to, kiedy tytuły te powstały; o ile natomiast są nimi

${ }^{83}$ Ibidem, k. 72.

${ }^{84}$ APR, Sąd Apelacyjny w Radomiu 1939-1945, sygn. 5, k. 126. Teza nr 17 Sądu Apelacyjnego w Radomiu z 27 marca 1943 r. 
ugody sądowe i przed sądami polubownymi zawarte lub tytuły oparte na aktach notarialnych (art. 527 pkt $5 \mathrm{kpc}$ ), sąd może stosować art. $269 \mathrm{kz}$.

2. Strona ubiegająca się o ulgi przewidziane w art. $269 \mathrm{kz}$ ma obowiązek twierdzić i w razie potrzeby udowodnić wszystkie przesłanki faktyczne w artykule tym wymienione; samo twierdzenie co do zajścia nadzwyczajnego wypadku nie wystarcza.

3. Sąd, odrzucając możność stosowania art. 269 kz i wobec braku innych szczególnych przepisów, nie jest władny nawet w szczególnych przypadkach jedynie ze „względów słuszności” rozkładać na raty świadczenie wypływające z umowy, nie jest też uprawniony do rozkładania na raty świadczenia, ustalonego prawomocnym orzeczeniem sądowym. Art. $107 \mathrm{kz}$ nie daje również podstawy ku temu ${ }^{85}$.

WSN w Radomiu uchylił wyrok sądu okręgowego oraz oddalił skargę apelacyjną od wyroku sądu grodzkiego. W uzasadnieniu wyroku ani razu nie powołano się na przedstawioną tezę Sądu Apelacyjnego w Radomiu, jednak argumentacja WSN w Radomiu pokrywa się z tą przedstawioną przez radomski sąd apelacyjny. Wyższy sąd niemiecki podniósł, że z pewnością materialna prawomocność zabrania wydania w tej samej sprawie orzeczenia sprzeciwiającego się pierwszemu wyrokowi. W przeciwnym razie nie można byłoby osiągnąć celu prawomocności, której zadaniem było przyczyniać się do zapewnienia możliwie największej pewności prawnej. Art. 269 kz, zdaniem WSN w Radomiu, dotyczył jedynie zobowiązań umownych, jak to jednoznacznie wynikało z brzmienia tego przepisu, a nie zobowiązań ustalonych prawomocnie wyrokami bądź wykonalnymi nakazami zapłaty. Nie mógł on więc służyć do podważania materialnej prawomocności, będącej filarem praworządności. Wyrok sądu okręgowego miał nie docenić doniosłości prawomocności i prowadziłby - w razie przyjęcia tego poglądu - do znaczącej niepewności prawnej i większego obciążenia sądów, zwłaszcza że dopuszczenie względów słuszności w swych skutkach zależne od okoliczności mogłoby wychodzić poza ramy zastosowania przepisu art. 269 kz. Według WSN w Radomiu należało przestrzegać materialnej prawomocności nawet wówczas, gdy skutek w danym przypadku z punktu widzenia osoby nim dotkniętej wydawał się niesprawiedliwy. Interes ogółu, jeśli chodziło o pewność prawną i „spokój prawny”, był bez porównania ważniejszy aniżeli interes jednostki ${ }^{86}$.

W wyżej przedstawionej sprawie sąd okręgowy ewidentnie stanął po stronie osób fizycznych (powodów) w sporze z Bankiem Spółdzielczym (pozwany). Sąd okręgowy, mając prawdopodobnie świadomość, że na podstawie art. $269 \mathrm{kz}$ nie można zmienić sposobu wykonania świadczenia orzeczonego prawomocnym orzeczeniem sądu, dokonał zmiany sposobu świadczenia (wnioskowane w pozwie

${ }^{85}$ Ibidem, k. 126.

${ }^{86}$ APR, Sąd Apelacyjny w Radomiu 1939-1945, sygn. 8, k. 73-75. Wyrok Wyższego Sądu Niemieckiego w Radomiu z 23 czerwca 1943 r. w sprawie cywilnej Np 5/43. 
rozłożenie na raty; bez zmiany istotnej treści samego świadczenia), opierając to rozstrzygnięcie wyłącznie na względach słuszności. Wyrok ten mógłby więc, przy istnieniu obiektywnego stanu wojny, stworzyć precedens do wzruszania wyroków wydanych przed wojną, które nie zostały jeszcze wyegzekwowane. Jak wskazał Sąd Apelacyjny w Radomiu, „względy słuszności” mogłyby według tej samej zasady nakazywać obniżenie takiego świadczenia czy nawet rozwiązanie umowy ${ }^{87}$.

Nie udało się ustalić, kto był inicjatorem złożenia przez kierownika Wydziału Sprawiedliwości w Urzędzie Gubernatora Dystryktu Radomskiego wniosku o wszczęcie procedury prawa sprawdzenia w niniejszej sprawie - czy była to wyłączna inicjatywa władz niemieckich, czy problem został zasygnalizowany przez radomski sąd apelacyjny. Na pewno na tle tej sprawy wydana została teza prawna, i to jeszcze przed wszczęciem procedury prawa sprawdzenia. Musiano dostrzec więc, że w omawianym orzeczeniu sądu okręgowego pojawia się szczególnie doniosłe zagadnienie prawne.

\section{PODSUMOWANIE}

Instytucja prawa sprawdzenia przez wyższe sądy niemieckie w GG prawomocnych orzeczeń sądów polskich (nieniemieckich) miała podobny charakter jak rewizja nadzwyczajna. W ten sposób realizowany był szczegółowy nadzór judykacyjny nad sądownictwem polskim (nieniemieckim), inicjowany przez organ władzy administracyjnej - kierownika Wydziału Sprawiedliwości w Urzędzie Gubernatora Dystryktu. Prawo sprawdzenia przysługiwało wobec wszystkich „rozstrzygnięć” sądu polskiego (nieniemieckiego), a więc także wobec postanowień (przedstanowczych) niekończących postępowania w sprawie. Żadna z przeanalizowanych spraw nie dotyczyła przypadków określonych w $§ 18$ rozporządzenia o sądownictwie polskim z 19 lutego 1940 r. związanych ze sprawdzaniem orzeczeń sądów polskich uprawomocnionych przez wejściem w życie tego rozporządzenia.

Interes publiczny wskazany przez prawo GG jako przesłanka do wszczęcia postępowania o sprawdzenie prawomocnych orzeczeń sądów polskich (nieniemieckich) utożsamiany był przez kierownika radomskiego wydziału sprawiedliwości wyłącznie z interesem narodu niemieckim. Analiza orzecznictwa WSN w Radomiu wykazała, że omawiana instytucja służyła uchylaniu i zmianie tych wyroków, które były niezgodne z prowadzoną przez okupantów niemieckich polityką w GG. Chodziło przede wszystkim o zagwarantowanie, że wyroki wydawane przez sądy polskie (nieniemieckie) nie staną na przeszkodzie prowadzonej eksploatacji ekonomicznej ludności (np. zakaz pomniejszania nieruchomości rolnych, co pro-

${ }^{87}$ APR, Sąd Apelacyjny w Radomiu 1939-1945, sygn. 5, k. 126. Teza nr 17 Sądu Apelacyjnego w Radomiu z 27 marca 1943 r. 
wadziłoby do zmniejszenia wielkości kontyngentów; zakaz orzekania świadczeń in natura). Sądownictwo niemieckie, poprzez zmiany wyroków, które służyły zwiększaniu i optymalizacji kontyngentów dostarczanych przez ludność polską, miało swój udział w ,publicznie usankcjonowanym niedożywianiu ludności autochtonicznej" ${ }^{88}$ w GG.

Wydawane przez WSN w Radomiu orzeczenia były w pełni zgodne z wnioskami przedstawionymi przez kierownika dystryktowego wydziału sprawiedliwości. Najprawdopodobniej to władze centralne GG wskazywały organom administracyjnym, na jakie kwestie powinny zwrócić uwagę w orzeczeniach sądów polskich (nieniemieckich). Świadczy o tym przywołane pismo kierownika Głównego Wydziału Sprawiedliwości w rządzie GG zwracające uwagę na orzekane świadczenia w naturze. Następnie władze powiatowe - starostowie i agronomowie powiatowi - nadzorowały podziały nieruchomości oraz obrót towarami zakazanymi przez prawo GG. Po ustaleniu, że jakiś wyrok sądu polskiego (nieniemieckiego) narusza te dyrektywy, przesyłano wniosek do dystryktowego wydziału sprawiedliwości o wszczęcie procedury sprawdzenia jako jedynej możliwości wzruszenia prawomocnego wyroku sądu. Faktycznie więc WSN w Radomiu w postępowaniach o sprawdzenie orzeczeń sadów polskich (nieniemieckich) nie miał autonomicznej pozycji w orzekaniu, lecz realizował cele polityki okupantów niemieckich w GG.

Tylko w kilku przypadkach WSN w Radomiu rozstrzygnął istniejące w praktyce sądownictwa w GG problemy prawne (ustalenie statusu prawnego gmin w GG; wyraźna zgoda na obrót nieruchomościami; interpretacja zasady rebus sic stantibus). Orzeczenia WSN w Radomiu były przesyłane przez kierownika radomskiego sądu apelacyjnego do wszystkich podległych mu sądów okręgowych. Znamienny przy tym jest przypadek powołania się przez stronę w jednej ze spraw na tezę prawną uchwaloną przez Sąd Apelacyjny w Radomiu. Wskazuje to na rolę, jaką pełniły tezy prawne, które nie tylko miały charakter ujednolicający orzecznictwo sądów polskich (nieniemieckich), ale mogły być też wykorzystywane jako argument przez strony w postępowaniach przed sądami niemieckimi.

Większość spraw, które podlegały sprawdzeniu przez WSN w Radomiu, miała cywilny charakter. Wynika to z faktu, że w sprawach karnych o właściwości sądu decydowała niemiecka prokuratura i znacznie wcześniej sądownictwo niemieckie mogło przejąć i osądzić sprawę, w której ujawnił się interes niemiecki. Rozpatrzone przez WSN w Radomiu sprawy karne w dwóch przypadkach dotyczyły ochrony prawnej Polaków wykonujących pracę na rzecz okupanta niemieckiego (strażnik więzienny, zastępca sołtysa). Raz chodziło o uniewinnienie skazanego za czyn zabroniony popełniony w związku z wykonywanymi rozkazami, w drugim

${ }^{88}$ Masowy rabunek produkcji rolnej doprowadził do skrajnego zmniejszenia przydziału żywności dla ludności miejscowej. Cytat z Sonji Schwaneberg, za: D. Brewing, W cieniu Auschwitz..., s. 137. 
przypadku zaostrzono wyrok za atak dokonany na urzędnika wykonującego swoje obowiązki służbowe. Trzecia sprawa karna dotyczyła pominięcia przez sąd polski (nieniemiecki) faktu sfałszowania karty zapotrzebowania na obuwie, która zdaniem WSN w Radomiu była dokumentem w rozumieniu prawa karnego.

W postępowaniach o sprawdzenie prawomocnych orzeczeń sądów polskich (nieniemieckich) przed WSN w Radomiu można wyróżnić trzy etapy. W pierwszym etapie sprawdzane były kwestie formalne: prawomocność sprawdzanego wyroku, termin oraz wskazanie we wniosku istnienia interesu publicznego. Przy czym, jak podkreślał WSN w Radomiu, tylko kierownik Wydziału Sprawiedliwości w Urzędzie Gubernatora Dystryktu Radomskiego miał kompetencje do oceny istnienia interesu publicznego $\mathrm{w}$ sprawdzeniu prawomocnego orzeczenia. $\mathrm{W}$ drugim etapie dokonywano oceny „sprawdzenia” orzeczenia sądu polskiego (nieniemieckiego). Formalnie ocena ta dotyczyła prawa obowiązującego w GG. Faktycznie jednak kryterium oceny była zgodność orzeczeń z celami polityki prowadzonej w GG. Po sprawdzeniu orzeczenia we wszystkich przebadanych przypadkach doszło do co najmniej częściowego uchylenia sprawdzanego orzeczenia. W takim wypadku WSN w Radomiu albo sam rozpatrywał sprawę, albo przekazywał ją właściwemu sądowi niemieckiemu. Przekazywane były te sprawy, w których nie wszystkie okoliczności zostały dostatecznie wyjaśnione przez sądy polskie (nieniemieckie), i niezbędne było przeprowadzenie postępowania dowodowego. W pozostałych przypadkach WSN w Radomiu opierał się na ustaleniach faktycznych sądów polskich (nieniemieckich) i sam wydawał orzeczenie. Ewentualnie dopuszczano dowód z urzędowej informacji od organów administracyjnych, pozwalającej WSN w Radomiu na wskazanie właściwej osoby do objęcia nieruchomości rolnej.

\author{
THE RIGHT TO REVIEW FINAL JUDGMENTS \\ OF THE POLISH (NON-GERMAN) COURTS \\ IN THE GENERAL GOVERNMENT DURING WORLD WAR II. \\ JUDICIAL DECISIONS OF THE GERMAN SUPERIOR COURT IN RADOM
}

\title{
Abstract
}

The purpose of the article is to characterize the course of review proceedings of the final judgments of the Polish (non-German) courts by the German Superior Court in Radom. The paper ascertains how the premise of "public interest," which was necessary to initiate proceedings, was interpreted by the Department of Justice in the Governor's Office of the Radom District. Moreover, the types of civil and criminal cases which were examined under this procedure are indicated. The purpose of this institution was to implement detailed judicial supervision of the Polish (non-German) judiciary. The right to review was available in relation to all the "rulings" of Polish (non-German) courts. Consequently, it was also applicable to non-final decisions which did not conclude the proceedings in a given case. 
An analysis of the judicial decisions of the German Superior Court in Radom demonstrates that the delineated institution had the purpose of overturning and changing those judgments which were incompatible with the German policy in the General Government. In the course of the proceedings which verified the judgments of Polish (non-German) courts, the German Superior Court in Radom did not have an autonomous and independent position in its adjudication. Instead, it adhered to the German policy in the General Government in order to realize the policy's objectives.

Keywords: General Government, Polish (non-German) Judiciary, Nazi law, World War II 